\title{
Can riparian vegetation shade mitigate the expected rise in stream temperatures due to climate change during heat waves in a human-impacted pre-alpine river?
}

\author{
Heidelinde Trimmel $^{1}$, Philipp Weihs ${ }^{1}$, David Leidinger ${ }^{1}$, Herbert Formayer ${ }^{1}$, Gerda Kalny ${ }^{2}$, and Andreas Melcher ${ }^{3}$ \\ ${ }^{1}$ Institute of Meteorology, University of Natural Resources and Life Science (BOKU), Vienna, Austria \\ ${ }^{2}$ Institute of Soil Bioengineering and Landscape Construction (IBLB), University of Natural Resources and \\ Life Science (BOKU), Vienna, Austria \\ ${ }^{3}$ Institute of Hydrobiology and Aquatic Ecosystem Management (IHG), University of Natural Resources and \\ Life Science (BOKU), Vienna, Austria
}

Correspondence: Heidelinde Trimmel (heidelinde.trimmel@ boku.ac.at)

Received: 13 May 2016 - Discussion started: 23 May 2016

Revised: 22 November 2017 - Accepted: 26 November 2017 - Published: 18 January 2018

\begin{abstract}
Global warming has already affected European rivers and their aquatic biota, and climate models predict an increase of temperature in central Europe over all seasons. We simulated the influence of expected changes in heat wave intensity during the 21 st century on water temperatures of a heavily impacted pre-alpine Austrian river and analysed future mitigating effects of riparian vegetation shade on radiant and turbulent energy fluxes using the deterministic Heat Source model. Modelled stream water temperature increased less than $1.5^{\circ} \mathrm{C}$ within the first half of the century. Until 2100 , a more significant increase of around $3{ }^{\circ} \mathrm{C}$ in minimum, maximum and mean stream temperatures was predicted for a 20 -year return period heat event. The result showed clearly that in a highly altered river system riparian vegetation was not able to fully mitigate the predicted temperature rise caused by climate change but would be able to reduce water temperature by 1 to $2{ }^{\circ} \mathrm{C}$. The removal of riparian vegetation amplified stream temperature increases. Maximum stream temperatures could increase by more than $4{ }^{\circ} \mathrm{C}$ even in annual heat events. Such a dramatic water temperature shift of some degrees, especially in summer, would indicate a total shift of aquatic biodiversity. The results demonstrate that effective river restoration and mitigation require re-establishing riparian vegetation and emphasize the importance of land-water interfaces and their ecological functioning in aquatic environments.
\end{abstract}

\section{Introduction}

Stream temperature is an important factor influencing the physical, chemical and biological properties of rivers and thus the habitat use of aquatic organisms (Davies-Colley and Quinn, 1998; Heino et al., 2009; Magnuson et al., 1979). Heino et al. (2009) suggest that freshwater biodiversity is highly vulnerable to climate change with extinction rates exceeding those of terrestrial taxa. Stream temperature is highly correlated with the assemblages of fish and benthic invertebrates along the river course (Dossi et al., 2015; Melcher et al., 2015). The duration and magnitude of the maximum summer stream temperatures in particular are limiting factors for the occurrence of many fish species. High temperatures may produce high physiological demands and stress while also reducing the oxygen saturation in the water column. The increased metabolic requirements together with the decreased oxygen availability can prove to be a limiting factor or even be lethal in combination; the average optimum temperature for cold water species is below $16^{\circ} \mathrm{C}$ (Matulla et al., 2007; Pletterbauer et al., 2015).

Continuous warming of water temperatures induces changes from cold water to warm water fish species assemblages and slow altitudinal shifts of species, if the habitat is suitable and no migration barriers exist. River continuum disruption and river dimension reduce the fish zone extent significantly (Matulla et al., 2007; Bloisa et al., 2013). Extreme events where lethal thresholds of stream temperature are ex- 
ceeded can cause a disruption of animal communities or even extinction of (cold water) species (Melcher et al., 2013; Pletterbauer et al., 2015). The largest uncertainties in forecasts of total suitable habitat are climate uncertainty (Wenger et al., 2013). All 230 stations of the Austrian hydrographic central office, with different elevations, distances from source and catchment areas recorded increases in stream temperature of $1.5^{\circ} \mathrm{C}$ during summer (June-August) and $0.7^{\circ} \mathrm{C}$ during winter (December-February) between 1980 and 2011 $\left(0.48^{\circ} \mathrm{C} \mathrm{decade}^{-1}\right)$ (BMLFUW, 2011). This change is not likely to be due to natural climatic cycles but is part of a long-term trend caused by anthropogenic changes in the atmosphere (APCC, 2014).

Air temperatures have been rising and are expected to continue to rise globally within the next century (IPCC, 2013). In eastern Austria, mean air temperature has risen by $2{ }^{\circ} \mathrm{C}$ since 1880 , which is more than double the $0.85^{\circ} \mathrm{C}$ rise recorded globally (Auer et al., 2014). A further temperature increase within the 21 st century is very likely (APCC, 2014). If emission scenario A1B is assumed, mean air temperature increases of $3.5^{\circ} \mathrm{C}$ over the level of the reference period $1961-$ 1990 by the end of the 21st century are expected in Austria (APCC, 2014; Gobiet et al., 2014).

Temperature extremes have changed markedly and extreme high temperature events, i.e. heat waves, are very likely to increase in the 21st century (APCC, 2014). Soil temperature is also expected to increase due to climate change and will influence stream temperatures via substrate heat conduction and groundwater flux (Kurylyk et al., 2015). For example, in Austria, near-surface groundwater body temperature is expected to rise by 0.5 to $1^{\circ} \mathrm{C}$ on average by 2050 (BMLFUW, 2011). Austria lies between two zones of opposing precipitation trends (IPCC, 2013). Northern Europe shows an increasing trend, while the Mediterranean has a decreasing trend (Böhm, 2006). In southeastern Austria, a precipitation decrease of about $10-15 \%$ has been recorded over the last 150 years (APCC, 2014; Böhm, 2012). Low flow discharge rates of rivers are likely to decrease by 10 to $15 \%$ by $2021-$ 2050 compared to 1976-2007 during all seasons (Nachtnebel et al., 2014; Mader et al., 1996; APCC, 2014).

For the study region during summer heat waves, neither changes in groundwater nor snowmelt contributions are expected (APCC, 2014). Heavy and extreme precipitation shows no clear increasing signal on average, but it is likely to increase from October to March (APCC, 2014). No clear trend of increasing wind speed (Matulla et al., 2008; Beniston, 2007) or increase in sunshine hours (Ahrens et al., 2014) has been detected but changes in the climate system may also include changes in those parameters (APCC, 2014).

Stream temperature is controlled by advection of heat, dispersion and the net energy fluxes acting on the surface and river bed. Net shortwave radiation is the dominant energy input causing diurnal and seasonal water temperature variability. Longwave radiation flux (Benyaha et al., 2012) as well as the turbulent fluxes of evaporation and convection, which are controlled by air temperature, vapour pressure, wind speed and net radiation, play an important role (Caissie et al., 2007; Garner et al., 2014; Hannah et al., 2008; Johnson, 2004).

One of the most influential factors regulating stream temperature is riparian vegetation (Caissie, 2006; Groom et al., 2011; Johnson, 2004; Moore et al., 2005; Rutherford et al., 1997). The streamside vegetation buffer width (Clark et al., 1999), vegetation density and average tree height all have a strong influence on stream temperature (Sridhar et al., 2004). Vegetation affects the sky view of the river and thereby shortwave (Holzapfel et al., 2013) and longwave radiation flux, evaporation and convection heat flux, which are highly correlated to the openness of the sky. The reduction of shortwave radiation can contribute significantly to reducing the heating of rivers during warmer summers (Sinokrot and Stefan, 1993; Parker and Krenkel, 1969; Rutherford et al., 1997).

There are different approaches to predicting stream temperature. Water temperature can be predicted using statistical functions (stochastic models) and its correlation (regression models) to known variables (e.g. air temperature, water temperature of the previous days or streamflow). Use of air temperature as a surrogate for future water temperature can lead to errors when linear (Erickson and Stefan, 2000; Webb and Nobilis, 1997) or non-linear (Mohseni et al., 1998) regression models are applied (Arismendi et al., 2014). Stochastic models used to determine the long-term annual component of temperatures and their short-term residuals separately yield good results (Caissie et al., 2001). Including a discharge term in the regression model can improve the model's performance during heat wave and drought (low flow) conditions, when water temperatures are most sensitive to air temperature (van Vliet et al., 2011). Energy balance models resolving all energy fluxes affecting a river system are the best suited to predict stream temperature (Caissie et al., 2007) but demand the most input data. Only these models are able to simulate energy flux changes caused by increased or decreased river shade.

Though the influence of vegetation on water temperature is evident, its ability to mitigate climate change is not yet sufficiently understood. Latent and sensible heat fluxes as well as longwave radiation balance are non-linearly dependent on air temperature. It is not obvious whether the same level of shade will always lead to the same rate of heat reduction. Shading caused by tall but less dense trees may allow exchange of air, while lower riparian vegetation may cause the same level of shade but would reduce air movement. Vegetation can reduce warming but may also reduce nightly cooling by altering the energy fluxes on a local scale, which can only be modelled using deterministic methods.

The conclusion may be drawn that many studies have already addressed the influence of riparian vegetation on stream water temperature using field measurements. Other studies used different methods to make short-term forecasts of stream temperature and few tried to answer the question of how climate change might increase stream water temper- 


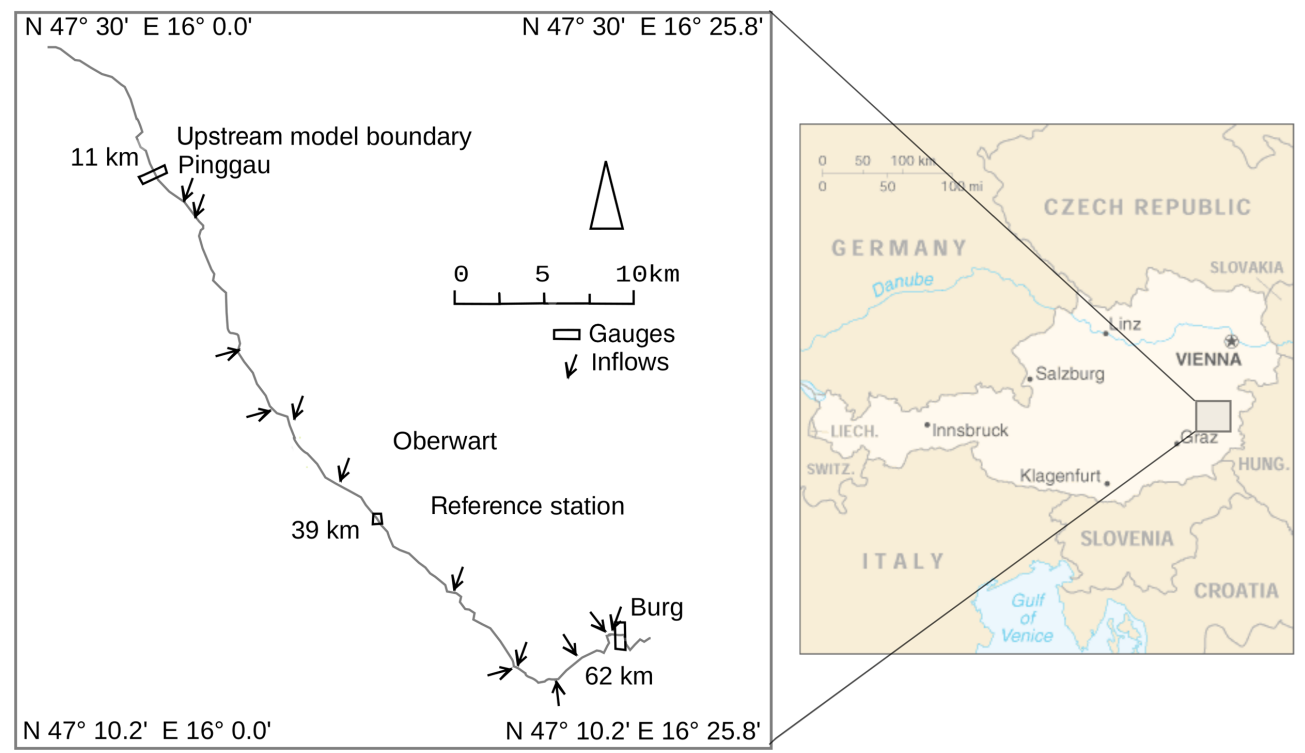

Figure 1. The study region in the Pinka showing gauges, tributaries and the reference station (kilometre markers shown as distance from source).

ature. One result or trend may however not be transferred from one river to another. Particular statements about the riparian vegetation's potential to mitigate the influence of climate change are only reliably valid for a given type of stream with its unique combination of morphologic and hydrologic parameters, local climate (Sinokrot and Stefan, 1993; Johnson, 2003; Steel and Fullerton, 2017) and regional climate change (Johnson and Wilby, 2015). Air temperature was normally used as a surrogate for stream temperature and energy flux variations in different river sections were not considered. The novel aspect of the present study is to investigate the influence of climate change and of riparian vegetation on the same river and attempt to make a realistic forecast of the riparian vegetation's potential to mitigate climate change in a specific river using a deterministic model.

The aims of the present study are therefore (1) to estimate the magnitude of stream temperature rise during extreme heat events caused by the expected rise in air temperature by the end of this century and (2) to investigate the ability of riparian vegetation to mitigate the expected water temperature rise within the habitat optimum of the site-specific aquatic fauna and (3) to analyse the possible variation of vegetation and potential interaction of vegetation and discharge with respect to climate change and their impact on water temperature.

\section{Methods}

Stream temperature was simulated with the 1-D energy balance and hydraulic Heat Source model (Boyd and Kasper, 2003) for $51 \mathrm{~km}$ along a section of river including upstream forested regions and tributaries. Temperature was simulated for each $500 \mathrm{~m}$ section of the river, which amounted to a total of 103 sites. First, the longitudinal changes of energy fluxes were analysed during the maximum heat wave, which took place in eastern Austria during summer 2013. Future heat wave episodes that are likely to occur during the climate periods 2016-2045, 2036-2065 and 2071-2100 in the study region were selected. Regional climate scenarios produced by the ENSEMBLE project (Hewitt et al., 2004) were further processed and the meteorological data extracted. The future upstream model water temperature was simulated by the methodology of Caissie et al. (2001). Heat Source was used to simulate the stream temperature of the Pinka for 12 future episodes and eight vegetation scenarios.

\subsection{Study region}

The river Pinka originates at $1480 \mathrm{~m}$ above sea level (a.s.l.) in the eastern Austrian Alps and discharges about $100 \mathrm{~km}$ downstream at $200 \mathrm{~m}$ a.s.l. into the river Rába. The catchment of the Pinka is $664 \mathrm{~km}^{2}$. According to Muhar et al. (2004), who categorized all Austrian rivers with catchment areas $>500 \mathrm{~km}^{2}$ corresponding to their annual discharge, the Pinka falls in the smallest of the five categories with $0-5 \mathrm{~m}^{3} \mathrm{~s}^{-1}$ mean annual discharge. The study region covers a $51 \mathrm{~km}$ stretch of the Pinka from the distance from source (DFS) of $11 \mathrm{~km}$ (559 ma.s.1.) near its most upstream gauge in Pinggau to DFS $62 \mathrm{~km}$ ( $240 \mathrm{~m}$.a.s.l.) close to the gauge at Burg (Fig. 1). For the first $10 \mathrm{~km}$, the river has a slope of $0.017 \mathrm{~m} \mathrm{~m}^{-1}$, whereas in the remaining section the slope is only $0.004 \mathrm{~m} \mathrm{~m}^{-1}$. The river bankfull width varied from 4 to $10 \mathrm{~m}$ (Fig. 2c). The maximum depth of the different river sections varied between 0.1 and $0.5 \mathrm{~m}$ and was $0.17 \mathrm{~m}$ on average. Only $4 \%$ of the reaches presently fall into the most nat- 

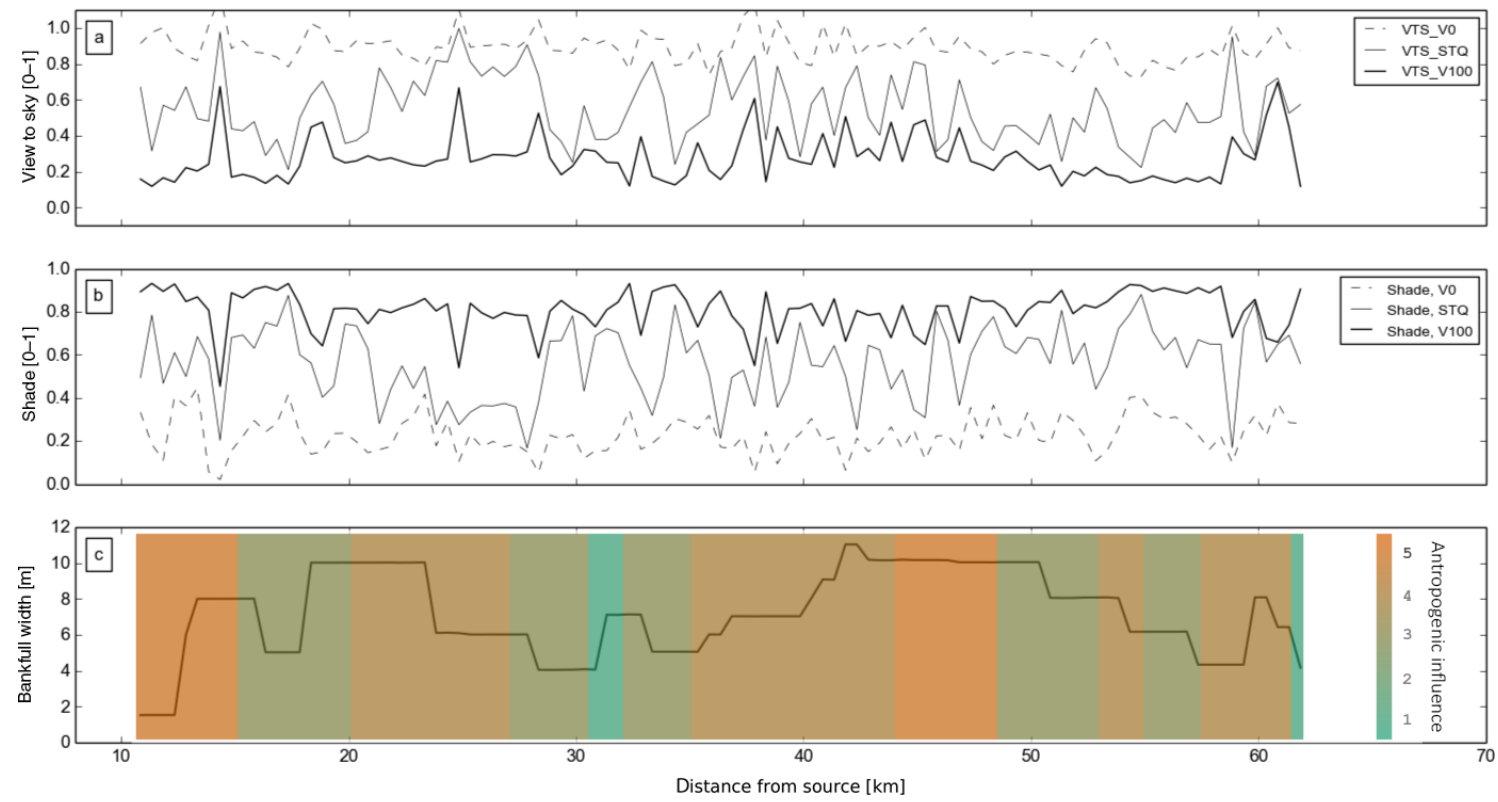

Figure 2. Characteristics of the Pinka. (a) The longitudinal distribution of view to sky (VTS) and (b) shade at the river's surface, (c) the bankfull width and the level of anthropogenic influence on the river. Legend on the right: entirely natural (1), slightly or not influenced (2), strongly influenced but with natural areas (3), continuously influenced with few natural areas (4) and completely regulated (5).

ural or the second category according to Ledochowski (2014) (Fig. 2c). On the other hand, $60 \%$ of reaches are classed as continuously influenced with no or very few natural sections (Fig. 2c).

Close to the source (DFS 0-12.5 km) the vegetation consists of commercial spruce forests (Picea abies) which undergo management. In the middle and downstream sections of the river, the near-natural deciduous riparian vegetation includes typical floodplain species of the region such as willows (Salix sp.) and alders (Alnus glutinosa and incana). In the downstream $80 \%$ of the river (from DFS 34 to $61 \mathrm{~km}$ ), riparian vegetation is reduced to one- or two-sided sparse tree plantations lining the river course for decorative purposes. These areas are mowed on a regular basis to prevent scrub growth. Other frequent trees like ash (Fraxinus excelsior), hazel (Corylus avellana), wild cherry (Prunus avium) and elder (Sambucus nigra) can be found along the whole river course. In this region, air temperature has risen by $2{ }^{\circ} \mathrm{C}$ since 1880 (Auer et al., 2014). Precipitation has declined by 10$15 \%$ in our study region, the largest reduction in precipitation in Austria (Auer et al., 2007; Böhm et al., 2009, 2012).

\section{Potential changes in vegetation cover}

Changes in vegetation height and density in floodplain forests in natural systems are mainly due to succession (Primack, 2000; Garssen et al., 2014; Rivaes et al., 2014). The present potential natural floodplain forest is in many areas reduced to narrow fringes accompanying the river, which are flooded at least annually. The river has been continu- ously straightened and regulated throughout the 20th century. Flood protection measures and land use pressure have further altered the river and riparian vegetation dynamics. The vegetation behind these fringes is in the transition zone between softwood and hardwood wetland, and a further change towards upland or zonal vegetation is expected via terrestrialization processes, well known in the Danube region (Birkel and Mayer, 1992; Egger et al., 2007). The dominant tree species present along the Pinka, Salix alba, Alnus glutinosa and Fraxinus excelsior, have a European-wide distribution (San-Miguel-Ayanz et al., 2016) so they are likely to defend their habitat. Some autochthonous species (Populus alba, Prunus avium, Salix caprea, Fraxinus excelsior, Carpinus betulus) which were present in 2013 are favoured by warmer climates (Kiermeyer, 1995; Roloff and Bärtels, 2006). Nonnative species like Robinia pseudoacacia and Acer negundo are already present in the study region and might enlarge their habitat at the expense of native species (Kiermeyer, 1995; Roloff and Bärtels, 2006). Changes in tree species in favour of warmth-loving plants from downstream regions of the Rába/Danube catchment are possible (Lexer et al., 2014). Generally, changes are likely to be not only driven by climatic but also anthropogenic factors such as plantation of foreign species, which is not foreseeable.

\subsection{Modelling vegetation influence on energy fluxes and stream temperature along the river}

Using the deterministic model Heat Source version 9 (Boyd and Kasper, 2003; Garner, 2007) the energy fluxes, hy- 
draulics and stream temperature were simulated along the Pinka. The generation of the input data sets is described in Sect. 2.3 below. Vegetation affects water temperature directly by reducing shortwave radiation input and reducing the view to sky (VTS) which affects longwave radiation balance and the turbulent heat fluxes. Longwave radiation and the turbulent heat fluxes are non-linearly dependent on air temperature. Short- and longwave energy flux, latent and sensible heat fluxes and conduction are taken into account:

$$
\begin{gathered}
\Phi_{\text {Total }}=\Phi_{\text {Solar }}+\Phi_{\text {Longwave }}+\Phi_{\text {Latent }} \\
+\Phi_{\text {Sensible }}+\Phi_{\text {Conduction }},
\end{gathered}
$$

where $\Phi_{\text {Total }}$ is the energy balance, $\Phi_{\text {Solar }}$ is the shortwave energy which is absorbed by the water column, $\Phi_{\text {Longwave }}$ the longwave radiation balance, $\Phi_{\text {Latent }}$ the latent heat flux, $\Phi_{\text {Sensible }}$ the sensible flux and $\Phi_{\text {Conduction }}$ is the conduction flux to the stream bed flux, and all of which refer to the stream surface, so latent heat flux is mostly negative.

\section{Shortwave radiation}

The amount of radiation entering the stream $\left(\Phi_{\text {SolarEnter }}\right)$ is the radiation unobstructed by shading $\left(\Phi_{\text {AboveTopo }}\right)$ reduced by topographic shade ( $\left.\Phi_{\text {TopoShade }}\right)$, bank shade ( $\left.\Phi_{\text {BankShade }}\right)$, vegetation shade ( $\Phi_{\text {VegShade }}$ ) and reflected from river surface ( $\left.\Phi_{\text {SolarRef }}\right)$.

$$
\begin{aligned}
& \Phi_{\text {SolarEnter }}=\Phi_{\text {AboveTopo }}-\Phi_{\text {TopoShade }} \\
& -\Phi_{\text {BankShade }}-\Phi_{\text {VegShade }}-\Phi_{\text {SolarRef }}
\end{aligned}
$$

If topographic or bank shade is present, the direct radiation fraction is reduced by the radiation entering in the affected angles. If vegetation shade is present, the direct radiation is reduced depending on the vegetation density using a formulation of Beer's law by the term $\Phi_{\text {VegShade }}$.

$\mathrm{RE}=-\log \left(\frac{1-\mathrm{VD}}{10}\right)$

$\Phi_{\text {VegShade }}=1-\exp \left(-\operatorname{RE}\left(\frac{\mathrm{LD}}{\cos \left(\operatorname{rad}\left(\theta_{\mathrm{s}}\right)\right)}\right)\right)$,

where $\mathrm{RE}$ is the riparian extinction, VD is vegetation density, $\mathrm{LD}$ is the distance from the river centre and $\theta_{\mathrm{S}}$ is the solar elevation angle. $\Phi_{\text {Solar }}$, which is finally absorbed by the water column is the amount of solar radiation entering the stream ( $\left.\Phi_{\text {SolarEnter }}\right)(E q .2)$ minus the amount that is absorbed in the river bed $\left(\Phi_{\text {SolarAbsorb }}\right)$ and reflected $\left(\Phi_{\text {SolarBedRef }}\right)$.

$$
\Phi_{\text {Solar }}=\Phi_{\text {SolarEnter }}-\Phi_{\text {SolarAbsorb }}-\Phi_{\text {SolarBedRef }}
$$

\section{VTS and longwave radiation balance}

The VTS is calculated using modified vegetation density $\mathrm{VD}_{\text {mod }}$ and the vegetation angle $\theta_{v}$. VTS is used to calculate the diffuse radiation entering below vegetation height, atmospheric longwave radiation $\Phi_{\text {LongwaveAtm }}$ (Eq. 7), longwave radiation emitted from vegetation $\Phi_{\text {LongwaveVeg }}$ (Eq. 6) and the reduction of wind speed at the river surface (Eq. 11).

$\mathrm{VTS}=1-\frac{\max \theta_{\mathrm{v}} \cdot V D_{\text {mod }}}{7 \cdot 90}$

Longwave radiation balance $\Phi_{\text {Longwave }}$ is the sum of all longwave components:

$$
\begin{aligned}
& \Phi_{\text {LongwaveAtm }}=0.96 \cdot \mathrm{VTS} \cdot \varepsilon \cdot \sigma \cdot\left(T_{\text {airK }}\right)^{4} \\
& \Phi_{\text {LongwaveVeg }}=0.96 \cdot(1-\mathrm{VTS}) \cdot 0.96 \cdot \sigma \cdot\left(T_{\text {airK }}\right)^{4} \\
& \Phi_{\text {LongwaveStream }}=-0.96 \cdot \sigma \cdot\left(T_{\text {prevK }}\right)^{4} \\
& \Phi_{\text {Longwave }}=\Phi_{\text {LongwaveAtm }}+\Phi_{\text {LongwaveVeg }} \\
& \quad+\Phi_{\text {LongwaveStream }},
\end{aligned}
$$

where $\varepsilon$ is the emissivity of the atmosphere, $\sigma$ the StefanBoltzmann constant, and $T_{\text {airK }}$ the air temperature and $T_{\text {prevK }}$ the stream temperature of the advected water in degrees Kelvin.

\section{Latent and sensible heat fluxes}

Latent heat flux ( $\left.\Phi_{\text {Latent }}\right)$ was calculated using the Penman method, which included the radiation balance:

$$
\begin{aligned}
& E_{\mathrm{a}}=1.51 \cdot 10^{-9}+1.6 \cdot 10^{-9} \cdot(w \cdot \mathrm{VTS}) \cdot\left(e_{\mathrm{s}}-e_{\mathrm{a}}\right) \\
& E=\frac{\frac{\Phi_{\mathrm{Rad}} \cdot \Delta}{\rho \cdot \mathrm{LHV}}+E_{\mathrm{a}} \cdot \gamma}{\Delta+\gamma} \\
& \Phi_{\text {Latent }}=-E \cdot \mathrm{LHV} \cdot \rho,
\end{aligned}
$$

where $E_{\mathrm{a}}$ is the aerodynamic evaporation, $w$ the wind speed $\left(\mathrm{ms}^{-1}\right), E$ the evaporation rate $\left(\mathrm{ms}^{-1}\right), \Phi_{\mathrm{Rad}}$ the sum of $\Phi_{\text {Longwave }}$ and $\Phi_{\text {SolarEnter }}, \Delta$ the slope of the saturation vapour vs. air temperature curve, $\rho$ the density of water $\left(\mathrm{kg} \mathrm{m}^{-3}\right)$, LHV the latent heat of vaporization $\left(\mathrm{J} \mathrm{kg}^{-1}\right)$ and $\gamma$ the psychrometric constant $\left(\mathrm{mb}^{\circ} \mathrm{C}^{-1}\right)$.

Sensible heat flux is calculated from evaporation via the Bowen ratio $\beta$ :

$$
\begin{aligned}
& \beta=\frac{\gamma \cdot\left(T_{\text {prev }}-T_{\text {air }}\right)}{e_{\mathrm{s}}-e_{\mathrm{a}}} \\
& \Phi_{\text {Sensible }}=\Phi_{\text {Latent }} \cdot \beta,
\end{aligned}
$$

where $T_{\text {prev }}$ is the stream temperature, $T_{\text {air }}$ is air temperature, $e_{\mathrm{s}}$ is the saturated vapour pressure and $e_{\mathrm{a}}$ the air vapour pressure.

\section{Conduction heat flux}

Conduction $\Phi_{\text {Conduction }}$ is dependent on the thermal conductivity of the sediment $\mathrm{TC}_{\mathrm{sed}}\left(\mathrm{Wm}^{-1}{ }^{\circ} \mathrm{C}^{-1}\right)$, the sediment depth $d_{\text {sed }}(\mathrm{m})$, sediment temperature $T_{\text {sed }}$ and water temperature $T_{\text {prev }}$ :

$\Phi_{\text {Conduction }}=\frac{\mathrm{TC}_{\mathrm{sed}} \cdot\left(T_{\mathrm{sed}}-T_{\mathrm{prev}}\right)}{\frac{d_{\mathrm{sed}}}{2}}$. 


\section{Water temperature}

The effect of the energy balance of the water column on stream temperature was calculated taking into account flow velocity and river morphology. The stream temperature increase $\Delta T$ caused by $\Phi_{\text {Total }}($ Eq. 1$)$ was calculated using

$\Delta \mathrm{T}=\frac{\Phi_{\text {Total }} \cdot \mathrm{d} t}{\left(\frac{A}{W_{\mathrm{w}}}\right) \cdot c_{\mathrm{H}_{2} \mathrm{O}} \cdot m}$,

where $A$ is the cross-sectional area of the river, $W_{\mathrm{w}}$ is the wetted width, the $c_{\mathrm{H}_{2} \mathrm{O}}$ is the specific heat capacity of water $\left(4182 \mathrm{~J} \mathrm{~kg}^{-1}{ }^{\circ} \mathrm{C}^{-1}\right)$ and $m$ is the mass of $1 \mathrm{~m}^{3}$ water which is $998.2 \mathrm{~kg}$.

Conclusively, Heat Source includes all aspects of vegetation changes on stream temperature during future episodes and the main processes needed to answer the research questions can be modelled with Heat Source.

A first model set-up and validation for usage at the Pinka during heat wave conditions was done by Trimmel et al. (2016). By fine-tuning the morphological input (bottom width, roughness parameter Manning's $n$ and sediment hyporheic thickness) and the wind parameterization, the model's validity could be considerably improved for the simulations used here. Tuning increased the coefficients of determination $\left(R^{2}\right)$ for water temperature stations of different vegetation height and density at DFSs 31, 35, 37, 39 and $48 \mathrm{~km}$ to $0.96-0.98$ (daily minimum), 0.96-0.99 (daily mean) and 0.94-0.98 (daily maximum). The measurements fit the simulation very well (hourly RMSE was $0.88^{\circ} \mathrm{C}$ averaged for all stream measurement stations), so we concluded that all assumptions were met and the model was appropriate to be used for predictions.

\subsection{Preparation of input}

\subsubsection{Meteorological input}

During the maximum heat wave event of 2013, field measurements were collected at the study site. Global radiation, air temperature, air humidity and wind speed were measured at a reference station located at DFS $39 \mathrm{~km}$ $47^{\circ} 16^{\prime} 11.055^{\prime \prime} \mathrm{N}, 16^{\circ} 13^{\prime} 47.892^{\prime \prime} \mathrm{E}, 300 \mathrm{~m}$ a.s.l. To link the measured microscale meteorological data to mesoscale meteorological data, a systematic intercomparison between the local meteorological stations of the Austrian Weather Service $(Z A M G)$ and the $1 \times 1 \mathrm{~km}$ gridded observational data set INCA (Haiden et al., 2011) was made. Since the local permanent meteorological stations of ZAMG were used to produce the gridded INCA data set, they are highly consistent. The comparison of the INCA data with the air temperature measured at our reference station close to the river showed an RMSE of $0.67^{\circ} \mathrm{C}$ and an $R^{2}$ of 0.99 for consecutive hourly measurements during summer half-year 2013 (1 April-30 September). So the INCA data set was used as a
Table 1. Mean 5-day air temperatures of modelled future heat wave episodes used as selection criteria, shown with equivalent values from the observed period for comparison.

\begin{tabular}{rrrrr}
\hline & $1 \mathrm{a}$ & $5 \mathrm{a}$ & $20 \mathrm{a}$ & Max \\
\hline $1981-2010(\mathrm{OBS})$ & 23.1 & 25.0 & 27.2 & 27.4 \\
$2016-2045(2030)$ & 23.4 & 26.6 & 27.2 & 29.0 \\
$2036-2065(2050)$ & 24.2 & 27.2 & 28.4 & 28.8 \\
$2071-2100(2085)$ & 28.1 & 30.6 & 31.0 & 32.0 \\
\hline
\end{tabular}

proxy to represent the local meteorological conditions within the catchment.

To obtain future meteorological conditions at the reference station, data were extracted from the regional climate models (RCMs) ALADIN (driven by the global climate model ARPEGE; Déqué et al., 1994), REMO and RegCM3 (both ECHAM5 driven; Roeckner et al., 2003, 2004). The aim was to estimate possible maximum temperature values; therefore, data from ALADIN, the climate model with the most extreme dry and hot summers, were selected. The RCMs were bias corrected using the quantile mapping technique (Déqué, 2007) based on the E-OBS data set (Haylock et al., 2008) and scaled. In a second step, the data were spatially localized to a $1 \mathrm{~km} \times 1 \mathrm{~km}$ grid encompassing the area under investigation using the Austrian INCA data set (Haiden et al., 2011). In a third step, the data were temporally disaggregated from a resolution of 1 day to $1 \mathrm{~h}$. Temperature was disaggregated based on the daily maximum and minimum temperatures using three piecewise continuous cosine curves (Koutsoyiannis, 2003; Goler and Formayer, 2012). The temperature data were elevation corrected with a lapse rate of $0.65^{\circ} \mathrm{C}$ per $100 \mathrm{~m}$.

\section{Selection of extreme heat events}

The period chosen as past reference period ("OBS") was an extreme heat wave that ran from 4 to 8 August 2013, which was the most intense heat wave of 2013. The mean air temperature of this episode was comparable to a 20-year return period 5-day event (Table 1) for the period 19812010. Future episodes were selected by choosing future heat wave events in three periods (2016-2045: "2030", 20362065: "2050", 2071-2100: "2085") in the summer months (June-August) that were simulated for the emission scenario A1B by the climate model ALADIN (Radu et al., 2008). The events were chosen by selecting periods when the 5day mean air temperature exceeded different thresholds using the percentiles of the 5-day mean air temperature of the three periods, which corresponded to an event with a 1-year (1a), 5-year (5a) or 20-year (20a) return period as well as the maximum heat wave event of the period (Max). The selection criteria are shown in Table 1 . The start was 14 days prior to the end of the episode to allow spin-up of the Heat Source model, so all episodes have equal length of 14 days. 


\subsubsection{Vegetation and morphology}

The riparian vegetation cover and river morphology of this region were investigated by Ledochowski (2014). First, aerial photographs were used to define the river centre line and a $50 \mathrm{~m}$ buffer on both sides, because the influence of riparian vegetation on the river is negligible beyond this point. Within this zone, areas of homogeneous structure, land use and ecological function were mapped by hand. Additional information such as height, density and dominant vegetation type were recorded as attributes of mapped features. To verify and complete the attributes, field mapping was done using custom-built checklists. The checklists included two tree levels, one shrub level and one herb level. The recorded parameters for each level were height, density, overhang and dominant species. Vegetation height was estimated with a precision of $\pm 5 \mathrm{~m}$, overhang with a precision of $\pm 1 \mathrm{~m}$ and density with a precision of $\pm 20 \%$. The inclination of the river slope as well as the roughness of the section (type of regulation, whether sinuous or straight) and type of substrate were noted. From these data sources, VTS (see Eq. 6) and percent shade were calculated (Fig. 2a, b). The river morphology parameters including river bankfull width (Fig. 2c), wetted width, average water depth and height of river to slope top were also measured.

The riparian vegetation data were obtained after the phenological phase of leaf development was finished and leaves were fully developed (Ellenberg, 2012). The river investigated here is strongly influenced anthropogenically and highly regulated. The degree of anthropogenic influence was categorized by Ledochowski (2014) according to Mühlmann (2010) into five categories: entirely natural (1), slightly or not influenced (2), strongly influenced but with natural areas (3), continuously influenced with few natural areas (4) and completely regulated (5) (see Fig. 2c). This categorization mainly describes constraints on bank and riverbed dynamics. The structure and substrate composition of stream bed and vegetation were additional parameters recorded by Ledochowski (2014). The entirely natural class is endowed with riparian vegetation of above $30 \mathrm{~m}$ height, vegetation densities of 76 to $100 \%$ and a riparian zone of more than $49 \mathrm{~m}$ in width. The continuously influenced areas coincide with reduced riparian vegetation strips and reduced vegetation height.

\section{Vegetation scenarios}

Taking into account all likely changes in tree species, no change in maximum vegetation height or density is predictable. Potential changes can only be induced by different vegetation management strategies as intentional clearings, plantations or mowing. A total of eight vegetation management scenarios were chosen to estimate the impact of different levels of vegetation shade on future heat waves. This also makes it possible to quantify potential changes to warmth- loving species of reduced height and density. The following scenarios have been considered.

Existing riparian vegetation (STQ) used the best available status quo input data for vegetation, bank and topographic shade as described in Ledochowski (2014). The average density including all land cover types was $66 \%$ (standard deviation of $17 \%$ ) and the average height was $9.4 \mathrm{~m}$. Only considering areas including trees larger than $15 \mathrm{~m}$ height, the average density rose to $76 \%$ (standard deviation of $11 \%$ ), ranging from 2 to $90 \%$. At the sheltered headwaters (DFS $20 \mathrm{~km}$ ), the vegetation density reached 0.89 . For V0 within a $50 \mathrm{~m}$ buffer, all vegetation parameters (vegetation height, density and overhang) were set to 0 so that no vegetation shading occurred. The V0 scenario corresponded to intentional clearings and mowing. V100 was defined as $30 \mathrm{~m}$ height, $8 \mathrm{~m}$ overhang and $90 \%$ vegetation density within a $50 \mathrm{~m}$ buffer which is representative of the densest riparian forests of STQ located in the Pinka catchment (Ledochowski, 2014). The V100 scenario represented the maximum possible level of vegetation shade. It is achievable by suspension of clearing and mowing activities as well as additional plantations of local tree and shrub species, which grow to different heights and form a well-structured shrub and tree layer. To maintain this scenario management, measures like replacement plantings and well-directed cuttings are necessary. An intermediate height scenario (V50) was defined as $15 \mathrm{~m}$ vegetation height and $90 \%$ vegetation density. A reduced density scenario (V70) was defined as $30 \mathrm{~m}$ vegetation height and vegetation density of $70 \%$. Additionally scenarios of vegetation density of $50 \%$ and full vegetation height (VD50, VH100), and vegetation height reduced by $50 \%$ and vegetation density of $70 \%$ (VD70, VH50) and vegetation density of $50 \%$ (VD50, VH50) were considered. River bank and topography were not changed in the vegetation scenarios. No river restoration in terms of restoring natural river bank and allowing natural river dynamics was assumed.

\subsubsection{Definition of sediment layer and conduction flux}

Heat Source uses only one substrate temperature, which is representative of the whole sediment layer. The depth of the sediment layer is set to $1 \mathrm{~m}$, which corresponds to the available geological information of the Pinka (Pahr, 1984). The substrate temperature used in the model is set equal to the stream temperature at the uppermost model point. For each consecutive model point, the substrate temperature is calculated depending on the local thermal conductivity, thermal diffusivity, layer depth, hyporheic exchange, the river morphological profile, the water temperature and the solar radiation received at the river bed. The sediment of this region is very inhomogeneous and the spatial distribution of the groundwater level is unknown (Pahr, 1984). For low flow conditions, it was assumed that there was no deep groundwater influence. 


\subsubsection{Definition of discharge}

During the analysed period of 4-8 August 2013, low flow conditions prevailed. The river flow volume increased from $0.18 \mathrm{~m}^{3} \mathrm{~s}^{-1}$ close to the upstream model boundary at DFS $13 \mathrm{~km}$ to $0.76 \mathrm{~m}^{3} \mathrm{~s}^{-1}$ at the downstream model boundary (DFS $62 \mathrm{~km}$ ). The mean flow velocity was $0.46 \mathrm{~ms}^{-1}$ and it took the river water about $30 \mathrm{~h}$ to traverse the studied length of the river.

The model was not sensitive to discharge rates. A decrease in discharge of the upstream boundary station of $0.01 \mathrm{~m}^{3} \mathrm{~s}^{-1}$ $(6 \%)$ led to an increase in average stream temperature from DFS 26 to $48 \mathrm{~km}$ of $0.04^{\circ} \mathrm{C}(0.2 \%)$ (Trimmel et al., 2016). Because the aim was to estimate the influence of vegetation shade, clear-sky periods were chosen where no or only minor precipitation events occurred, so discharge was fixed at mean low flow (MLF) conditions. MLF was defined as the average of all daily discharges below the $5 \%$ discharge of the climate period 1981-2010. The mean low flow conditions of the gauging station at Pinggau, DFS $13 \mathrm{~km}$ (MLF of $0.143 \mathrm{~m}^{3} \mathrm{~s}^{-1}$ ), which is maintained by the Hydrographischer Dienst Österreich, were used in the model. At the other end of the study region, at DFS $62 \mathrm{~km}$, the corresponding flow volume was $0.795 \mathrm{~m}^{3} \mathrm{~s}^{-1}$. To take into account potential reductions of discharge, a scenario of MLF discharge $-15 \%$ (MLF-15 of $0.122 \mathrm{~m}^{3} \mathrm{~s}^{-1}$ ), which is a $5 \%$ reduction of the mean annual discharge - was calculated.

\subsubsection{Upstream boundary stream temperature}

Stream temperature and discharge were used as upstream boundary conditions. For the 2013 episode, these values rely on observations of the gauging station at Pinggau which is maintained by the Hydrographischer Dienst Österreich and a stream temperature measurement station maintained by the authors. To obtain equivalent data for future conditions, the maximum water temperature was first modelled at DFS $11 \mathrm{~km}$ using the expected air temperature as input (Mohseni et al., 1998). The water temperature was split into two components: the long-term seasonal component (or annual component) and the short-term non-seasonal component (or residuals series) (Caissie et al., 2001). The annual component was calculated according to the method of Kothandaraman (1971) and the residuals were calculated with a stochastic second-order Markov model after Cluis (1972) and Salas et al. (1980). Observed hourly water temperatures $(N=12.537)$ over the period 7 July 2012 to 9 September 2014 were used to fit the model. The coefficient of determination $R^{2}$ between observed and predicted water temperature for this period was 0.96 and the RMSE was $0.68^{\circ} \mathrm{C}$. For the summer half-year 2013 (April-September), the $R^{2}$ was 0.89 and the RMSE was $0.80^{\circ} \mathrm{C}$. To take into account the climatic trend caused by the warming of the land surface (Kurylyk et al., 2015), the difference between the moving average over a 30-year climate period and the reference period 1981-2010 was added to the annual component.

\subsubsection{Input data of tributaries}

The discharge levels and water temperature of the Pinka at the upstream model boundary and its five main tributaries were measured during the 2013 episode in the field by the authors and by two permanent gauging stations. The remaining unmeasured tributaries added less than $5 \%$ discharge each. Their future water temperatures were synthesized using the daily fluctuations of the water temperature at the upstream model boundary with the adding of a fixed offset depending on the distance of the inflow to the upstream model boundary. Missing discharge information was supplemented using proportions of the discharge levels of the gauge at Burg (DFS $62 \mathrm{~km}$ ) as measured during 2013.

\section{Results}

\subsection{Influence of vegetation shade and energy fluxes on stream temperatures during the heat episode of 2013 along the river}

In order to interpret the influence of vegetation shade on future water temperature, it is important to understand the influence of vegetation shade on the present conditions first. The mean VTS for the study region under current conditions (STQ) was 0.55. If all vegetation was to be removed (V0), there would still be some remaining shade caused by topography and the river bank, which reduces the maximum VTS value to 0.89 . If maximum vegetation was assumed (V100), the value of VTS would be strongly reduced but would still amount to 0.16 on average because a $90 \%$ vegetation density was assumed. Peaks in VTS were found at broader river sections or sections oriented east-west (Fig. 2a). The percentage shade is similar to the inverse of VTS but differs, as the south orientation is of importance (Fig. 2b).

During the STQ scenario, the most important energy inputs on the river surface during the study period were shortwave radiation flux with an average of $101.6 \mathrm{~W} \mathrm{~m}^{-2}$ (Fig. 3a), sensible heat flux with an average of $39.9 \mathrm{~W} \mathrm{~m}^{-2}$ (Fig. 3d) and longwave radiation with an average of $17.2 \mathrm{~W} \mathrm{~m}^{-2}$ (Fig. 3b). Conduction only amounted to $1.3 \mathrm{~W} \mathrm{~m}^{-2}$ on average (Fig. 3e). The relative percentage of shortwave radiation balance, longwave radiation balance and sensible heat flux was 64,11 and $25 \%$ of the inputs, respectively, that heated the water column. The main energy output was latent heat flux (Fig. 3c).

For the V0 and V100 scenarios, the characteristic of the longitudinal energy fluxes remained the same. During the V0 scenario, the relative percentage of shortwave radiation balance increased $(73 \%)$, while longwave radiation balance $(7 \%)$ and sensible heat flux (18\%) decreased. During the V100 scenario, the trend was opposite. Shortwave radiation 

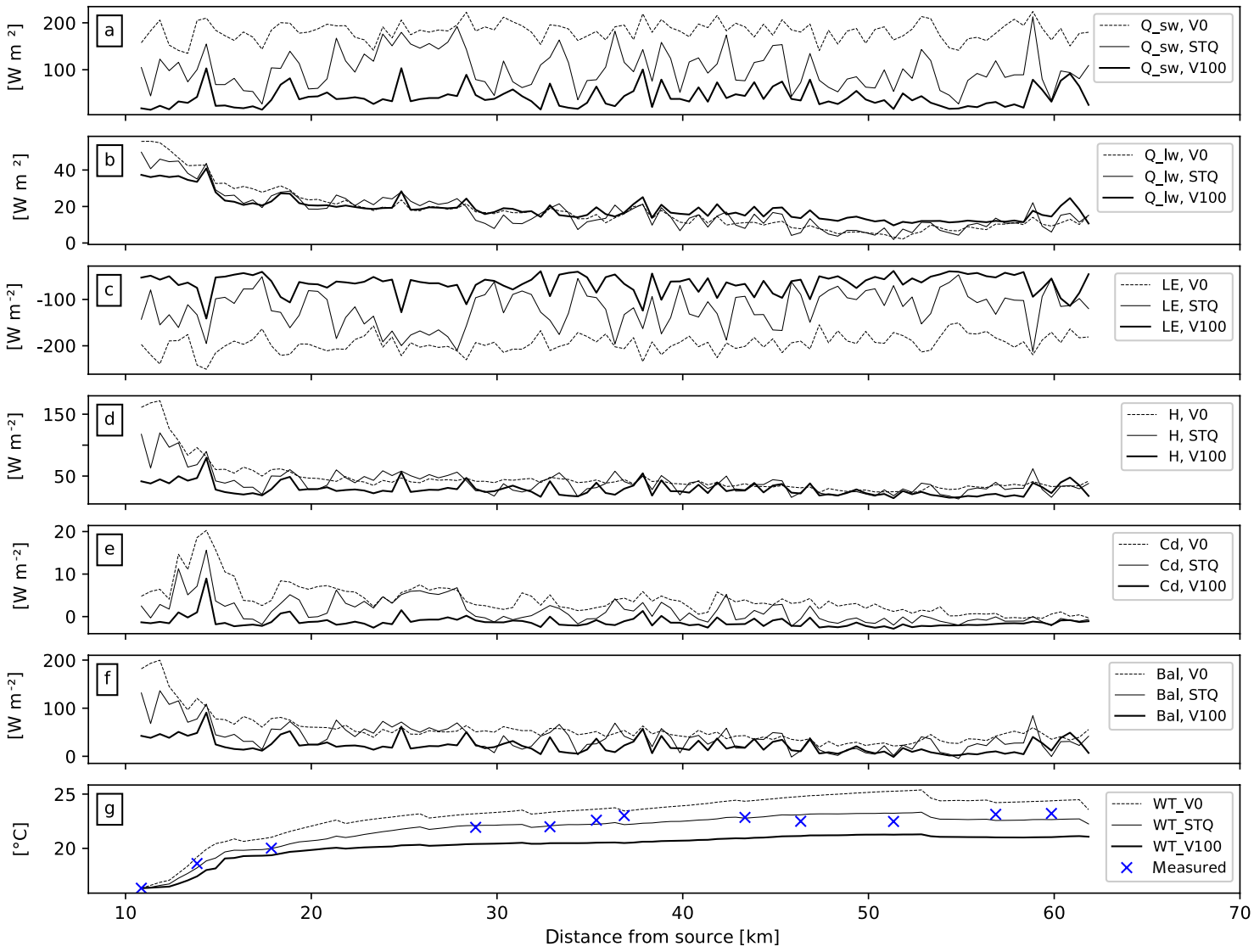

Figure 3. Comparison of (a) the calculated shortwave, (b) longwave radiation balance, (c) latent and (d) sensible heat fluxes, (e) conduction heat flux, (f) total energy balance, and (g) measured (measured) and simulated (WT) water temperature for the heat wave episode 4-8 August 2013 along the Pinka for three vegetation scenarios: no vegetation (V0), existing vegetation (STQ) and maximum vegetation (V100).

balance decreased $(47 \%)$ and longwave radiation balance (21\%) and sensible heat flux (32\%) increased (Fig. 3a-e).

Looking at the longitudinal distribution of energy fluxes along the river, it can be seen that sensible heat flux and longwave radiation flux as well as conduction showed their highest values close to the source during all vegetation scenarios. This leads to a rapid increase in the water temperature of the cool spring water, which is clearly seen in both measured and simulated data (Fig. 3g). All energy fluxes were dependent on the degree of openness to the sky and showed the same pattern along the river (Fig. 3a-f). Shortwave radiation and latent heat flux in particular were strongly influenced by the value of the VTS and showed distinct reductions of up to $70 \%$ where shading occurred (Fig. 3a, c).

The energy balance was positive on average along the whole river (Fig. 3f). The V0 scenario showed the highest and the V100 scenario the lowest net energy with mean values of 55, 40 and $22 \mathrm{~W} \mathrm{~m}^{-2}$ for the V0, STQ and V100 scenarios, respectively (Fig. 3f). The greatest differences between the different vegetation scenarios were found close to the source, where, during the V0 scenario, up to $200 \mathrm{~W} \mathrm{~m}^{-2}$ net energy was available to heat the water column (Fig. 3f), while during the V100 scenario the corresponding figure was only $91 \mathrm{~W} \mathrm{~m}^{-2}$. The positive energy balance can explain the gradual warming of the stream temperature along the river (Garner et al., 2014) which can be seen in Fig. 3g. The continuous downstream warming is reversed at about DFSs 16, $22,26.5,32,43.5$ and $53.5 \mathrm{~km}$ by about $0.5^{\circ} \mathrm{C}$ for short distances caused by the addition of cooler water from tributaries (Fig. 3g).

\subsection{Future climate and advective input}

The selection criteria mean air temperature of modelled scenarios increased depending on the return period of the event (Table 1). Apart from the 1a and 5a events of 2030 and the 1a event of 2050, all modelled events were warmer than the 2013 heat wave. Air humidity during the selected events decreased slightly by the end of the century (Table 2). In the 20-year return period event of 2050, wind speeds were higher $\left(1.1 \mathrm{~m} \mathrm{~s}^{-1}\right)$ than in $2030\left(0.9 \mathrm{~m} \mathrm{~s}^{-1}\right)$ and $2085\left(0.8 \mathrm{~m} \mathrm{~s}^{-1}\right)$ (Table 2). The average global radiation received during 
Table 2. Mean and daily maximum air temperatures, air humidity, wind speed, global radiation at the reference station and water temperature at the upstream model boundary averaged for the selected 5-day heat episodes in 2013 and the 1a, 5a, 20a and Max events of the climate periods centred on 2030, 2050 and 2085. For 2013 (OBS), measured values of the reference station $2 \mathrm{~m}$ above the river (M.) and interpolated measurement data from the INCA (I.) data set are shown.

\begin{tabular}{|c|c|c|c|c|c|c|c|c|c|c|c|c|c|c|}
\hline & \multicolumn{2}{|c|}{ OBS } & \multicolumn{4}{|c|}{2030} & \multicolumn{4}{|c|}{2050} & \multicolumn{4}{|c|}{2085} \\
\hline & M. & I. & $1 \mathrm{a}$ & $5 a$ & $20 \mathrm{a}$ & $\operatorname{Max}$ & $1 \mathrm{a}$ & $5 a$ & $20 \mathrm{a}$ & $\operatorname{Max}$ & 1a & $5 a$ & $20 \mathrm{a}$ & Max \\
\hline $\begin{array}{l}\text { Air temp. } \\
\left(\text { mean) }\left({ }^{\circ} \mathrm{C}\right)\right.\end{array}$ & 26.2 & 27.2 & 23.3 & 26.6 & 27.2 & 29.0 & 24.2 & 27.2 & 28.4 & 28.8 & 28.1 & 30.6 & 31.0 & 32.0 \\
\hline $\begin{array}{l}\text { Air temp (mean } \\
\text { daily max }\left({ }^{\circ} \mathrm{C}\right)\end{array}$ & 34.5 & 35.7 & 30.0 & 33.7 & 34.6 & 37.5 & 29.5 & 33.7 & 35.9 & 36.9 & 34.8 & 38.2 & 39.6 & 39.0 \\
\hline $\begin{array}{l}\text { Air humidity } \\
(\%)\end{array}$ & 62 & 55 & 73 & 57 & 55 & 53 & 54 & 56 & 56 & 60 & 58 & 51 & 48 & 52 \\
\hline $\begin{array}{l}\text { Wind speed } \\
\left(\mathrm{m} \mathrm{s}^{-1}\right)\end{array}$ & 0.6 & 1.4 & 0.7 & 0.9 & 0.9 & 1.0 & 1.3 & 1.1 & 1.1 & 0.8 & 1.3 & 1.2 & 0.8 & 0.9 \\
\hline $\begin{array}{l}\text { Global rad. } \\
\left(\mathrm{MJ} \mathrm{m}^{-2} \mathrm{~d}^{-1}\right)\end{array}$ & 24.6 & 24.6 & 23.4 & 25.0 & 28.0 & 29.0 & 24.9 & 28.7 & 23.1 & 21.7 & 27.3 & 24.5 & 23.8 & 20.9 \\
\hline $\begin{array}{l}\text { Boundary water } \\
\text { temperature }\left({ }^{\circ} \mathrm{C}\right)\end{array}$ & 16.3 & 16.3 & 14.1 & 15.9 & 16.0 & 16.8 & 15.6 & 16.2 & 17.0 & 17.5 & 17.5 & 19.4 & 20.4 & 20.3 \\
\hline
\end{tabular}

each event per day was different for each event as well. For the 20-year return event in 2030, global radiation was $28 \mathrm{MJ} \mathrm{m}^{-2} \mathrm{~d}^{-1}$, i.e. higher than the same scenario in 2050 $\left(23.1 \mathrm{MJ} \mathrm{m}^{-2} \mathrm{~d}^{-1}\right)$ and $2085\left(23.8 \mathrm{MJ} \mathrm{m}^{-2} \mathrm{~d}^{-1}\right)$. During the 20 -year return event of 2085 , on the other hand, global radiation was higher than the Max event $\left(20.9 \mathrm{MJ} \mathrm{m}^{-2} \mathrm{~d}^{-1}\right)$ of this climate period (Table 2).

For the mean water temperature at the model boundary, an increase of $+4.1^{\circ} \mathrm{C}$ for a 20 -year return event of 2085 with respect to 2013 levels was simulated (Table 2). For the Max event of 2085 , which had $2.2 \mathrm{MJ} \mathrm{m}^{-2} \mathrm{~d}^{-1}$ lower global radiation input, a slightly lower temperature increase $\left(+4.0^{\circ} \mathrm{C}\right)$ was simulated (Table 2).

The extraction of future climate data was based on the location of the INCA grid. INCA data for the heat event in 2013 were compared with data measured directly at the river. The INCA data assume a greater distance to the river surface and show higher mean and maximum air temperatures but also lower air humidity and higher wind speed. This difference in meteorological input data resulted in $0.1^{\circ} \mathrm{C}$ higher than measured mean water temperature (Table 3). Maximum water temperature was affected as well, with INCA showing a reduction of $0.3^{\circ} \mathrm{C}$ below measured values. Minimum water temperature was $0.6^{\circ} \mathrm{C}$ warmer when INCA data input were used. In order to directly compare the 2013 event with the future scenarios, the simulation using the INCA data of 2013 is referred to as "20a OBS" hereafter.

\subsection{Future stream temperatures}

\subsubsection{At DFS 39 km}

To analyse future changes, the initial focus was upon the reference station in the centre of the study region at DFS $39 \mathrm{~km}$.
As a temporal reference, the focus was placed on the 20-year return period events of the 2071-2100 climate period as it represents the maximum expected temperature rise.

The mean water temperature of the Pinka under MLF conditions with unchanged riparian vegetation (STQ) at DFS $39 \mathrm{~km}$ during the 20a heat wave event for the periods 2016 2045, 2036-2065 and 2071-2100 was predicted to be 22.4, 22.6 and $25.5^{\circ} \mathrm{C}$, respectively (Fig. 4, Table 3). The corresponding predicted maximum water temperatures were 25.0, 24.8 and $27.3{ }^{\circ} \mathrm{C}$. These predictions represent a significant increase over the mean temperatures of the $20 \mathrm{a}$ event of the OBS period of $22.5^{\circ} \mathrm{C}$ (maximum temperature: $24.4^{\circ} \mathrm{C}$ ) by the end of the century.

For mean temperatures, a minor increase in water temperature was predicted for the first half of the century even for extreme heat events with a 20 -year return period (Table 4 ). However, by the end of the century (2071-2100), a remarkable increase in minimum temperatures of $+3{ }^{\circ} \mathrm{C}$ was modelled. Maximum water temperatures also showed increases. For the period 2016-2045, maximum temperatures increased more rapidly than mean temperatures with a change over baseline conditions of $+0.6^{\circ} \mathrm{C}$. By $2071-2100$, the increase in maximum temperatures was predicted to be $2.9^{\circ} \mathrm{C} \mathrm{com}$ pared to the OBS period, which was similar to the predicted increase in mean and minimum water temperatures (Table 4).

Supposing the existing vegetation was removed (V0), the mean water temperature reached $26.7^{\circ} \mathrm{C}$ during 20 -year return period heat events at the end of the century, which was $4.2^{\circ} \mathrm{C}$ above the level of the STQ scenario of the OBS period. Maximum temperatures reached $28.9^{\circ} \mathrm{C}$, which is $4.5^{\circ} \mathrm{C}$ more than in the STQ scenario of the OBS period (Fig. 4, Tables 3,4$)$. Under conditions of maximum riverine vegetation (V100), the expected mean water temperature was predicted to reach only $23.9^{\circ} \mathrm{C}$, which is $1.4^{\circ} \mathrm{C}$ above the level of the 
Table 3. Daily minimum, mean and maximum 5-day mean water temperatures of the 5-day episodes averaged over the Pinka during the 1a, 5a, 20a and Max episodes for the climate periods centred on 2030, 2050 and 2085 and mean low flow discharge at DFS $39 \mathrm{~km}$. For 2013 (OBS), the measured values of the reference station $2 \mathrm{~m}$ above the river (Meas.) and interpolated measurement data from the INCA data set used as input are compared.

\begin{tabular}{lrrr|rrr|rrr}
\hline & \multicolumn{3}{c}{ Max. } & \multicolumn{3}{c|}{ Mean } & \multicolumn{3}{c}{ Min. } \\
\cline { 2 - 9 } & V0 & STQ & V100 & V0 & STQ & V100 & V0 & STQ & V100 \\
\hline OBS Meas. & 26.6 & 24.7 & 22.4 & 23.8 & 22.4 & 20.7 & 20.2 & 19.5 & 18.5 \\
OBS INCA & 26.1 & 24.4 & 22.1 & 23.7 & 22.5 & 20.8 & 21.0 & 20.1 & 19.2 \\
2030_1a & 24.5 & 23.1 & 20.7 & 21.5 & 20.4 & 18.6 & 16.5 & 16.5 & 16.3 \\
2030_5a & 25.9 & 24.3 & 22.1 & 22.5 & 21.3 & 19.7 & 17.8 & 17.2 & 16.5 \\
2030_20a & 27.0 & 25.0 & 22.5 & 22.2 & 22.4 & 20.2 & 19.4 & 18.2 & 17.2 \\
2030_Max & 27.2 & 25.7 & 23.5 & 24.8 & 23.4 & 21.6 & 21.9 & 20.8 & 19.5 \\
2050_1a & 24.3 & 22.6 & 20.0 & 21.6 & 20.4 & 18.9 & 19.0 & 18.2 & 17.3 \\
2050_5a & 26.5 & 24.8 & 22.2 & 23.7 & 22.3 & 20.5 & 20.4 & 19.5 & 18.4 \\
2050_20a & 26.6 & 24.8 & 23.0 & 23.7 & 22.6 & 21.3 & 20.2 & 19.9 & 18.9 \\
2050_Max & 27.5 & 25.9 & 23.7 & 25.1 & 23.9 & 22.2 & 22.5 & 21.5 & 20.4 \\
2085_1a & 28.6 & 24.9 & 23.1 & 26.2 & 22.5 & 21.7 & 22.3 & 18.8 & 18.8 \\
2085_5a & 29.0 & 27.3 & 25.0 & 26.5 & 25.3 & 23.7 & 24.1 & 23.0 & 21.7 \\
2085_20a & 28.9 & 27.3 & 25.5 & 26.7 & 25.5 & 23.9 & 23.6 & 22.9 & 21.7 \\
2085_Max & 29.3 & 27.8 & 25.7 & 27.1 & 26.0 & 24.6 & 25.0 & 24.1 & 23.0 \\
\hline
\end{tabular}

Table 4. Differences between the 20a event of the OBS period (2013) (with mean low flow discharge) of predicted maximum, mean and minimum water temperatures for the 1a, 5a, 20a and Max events at DFS $39 \mathrm{~km}$ for the climate periods centred on 2030,2050 and 2085 for vegetation scenario V0 (no vegetation), STQ (vegetation unchanged) and V100 (maximum vegetation).

\begin{tabular}{lrrr|rrr|rrr}
\hline & \multicolumn{3}{c}{ Max. } & \multicolumn{3}{c|}{ Mean } & \multicolumn{3}{c}{ Min. } \\
\cline { 2 - 10 } & V0 & STQ & V100 & V0 & STQ & V100 & V0 & STQ & V100 \\
\hline OBS INCA & 1.7 & 0 & -2.3 & 1.2 & 0 & -1.7 & 0.9 & 0 & 0.9 \\
2030_1a & 0.1 & -1.3 & -3.7 & -1 & -2.1 & -3.9 & -3.6 & -3.6 & -3.8 \\
2030_5a & 1.5 & -0.1 & -2.3 & 0 & -1.2 & -2.8 & -2.3 & -2.9 & -3.6 \\
2030_20a & 2.6 & 0.6 & -1.9 & 0.3 & -0.1 & -2.3 & -0.7 & -1.9 & -2.9 \\
2030_Max & 2.8 & 1.3 & -0.9 & 2.3 & 0.9 & -0.9 & 1.8 & 0.7 & -0.6 \\
2050_1a & -0.1 & -1.8 & -4.4 & -0.9 & -2.1 & -3.6 & -1.1 & -1.9 & -2.8 \\
2050_5a & 2.1 & 0.4 & -2.2 & 1.2 & -0.2 & -2 & 0.3 & -0.6 & -1.7 \\
2050_20a & 2.2 & 0.4 & -1.4 & 1.2 & 0.1 & -1.2 & 0.1 & -0.2 & -1.2 \\
2050_Max & 3.1 & 1.5 & -0.7 & 2.6 & 1.4 & -0.3 & 2.4 & 1.4 & 0.3 \\
2085_1a & 4.2 & 0.5 & -1.3 & 3.7 & 0 & -0.8 & 2.2 & -1.3 & -1.3 \\
2085_5a & 4.6 & 2.9 & 0.6 & 4 & 2.8 & 1.2 & 4 & 2.9 & 1.6 \\
2085_20a & 4.5 & 2.9 & 1.1 & 4.2 & 3 & 1.4 & 3.5 & 2.7 & 1.6 \\
2085_Max & 4.9 & 3.4 & 1.3 & 4.7 & 3.5 & 2.1 & 4.9 & 4 & 2.9 \\
\hline
\end{tabular}

STQ scenario during 2013 (Fig. 4, Tables 3, 4). The maximum temperature reached in this scenario is $25.5^{\circ} \mathrm{C}$ which is only $1.1^{\circ} \mathrm{C}$ above the maximum event of the OBS period (Fig. 4, Tables 3, 4).

Vegetation was not able to compensate fully for the temperature increase expected by the end of the century. For the climate period 2036-2065 though, riverine vegetation had the potential to more than compensate for climate change during extreme events and could even cause a cooling of -1.2 on average and $-1.4{ }^{\circ} \mathrm{C}$ with respect to maximum temperatures (Table 4).

\subsubsection{Longitudinal distribution}

During the 2013 heat wave event for the STQ scenario, the stream temperatures increased between the upstream model boundary at DFS $11 \mathrm{~km}$ and DFS $62 \mathrm{~km}$ by about $7^{\circ} \mathrm{C}$ (Fig. 3). Looking at the longitudinal distribution of water temperature along the river, it can be seen that increases in mean stream temperature caused by increases of future air temperature affected all parts of the river (Fig. 5a-c).

The maximum values showed a similar pattern to the mean values on a higher level. The average difference between mean and maximum values of the STQ scenario was 3.92, 

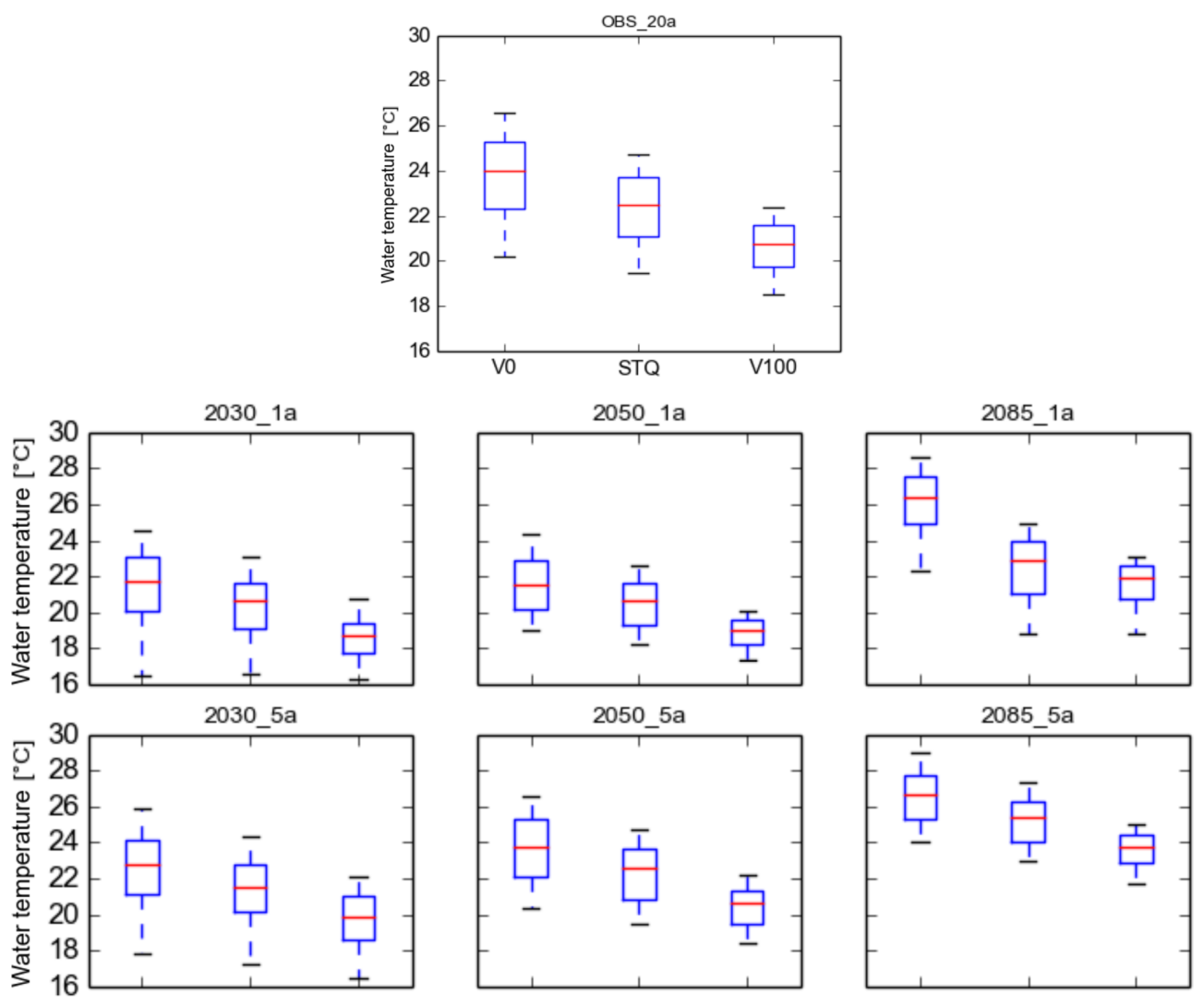

2085_5a
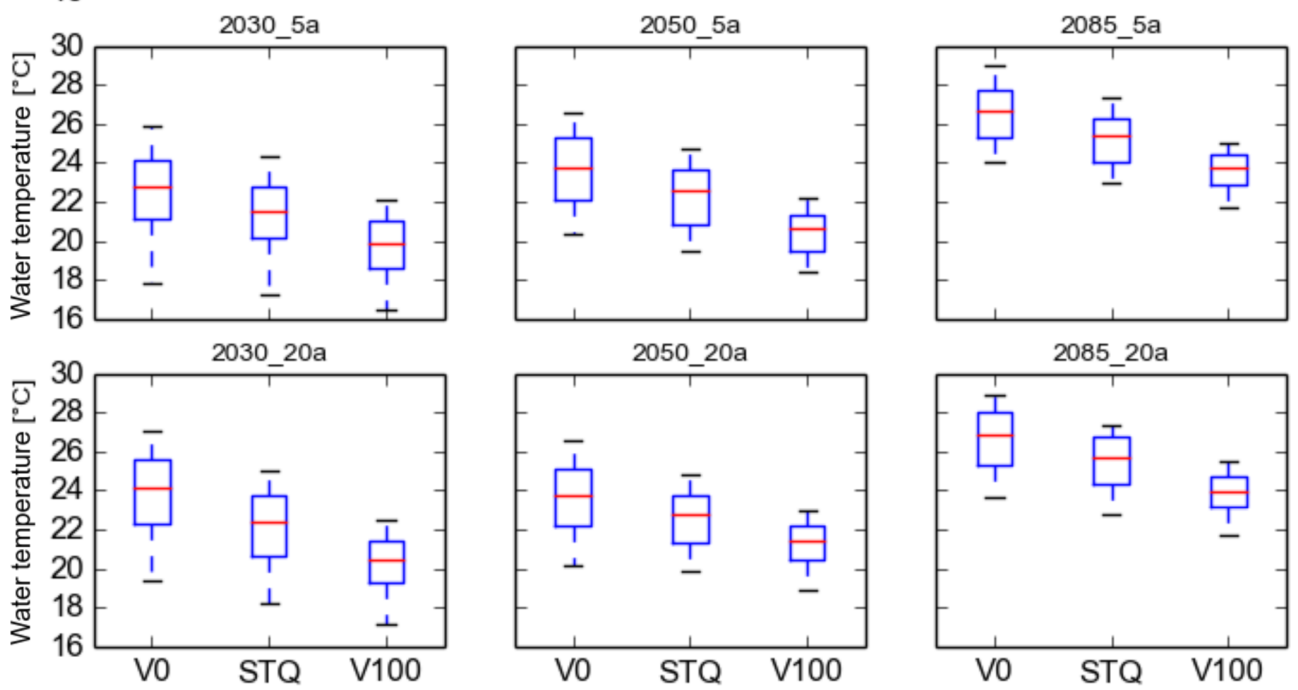

Figure 4. Box-and-whisker plots showing the 5-day mean water temperature distributions during the 1a, 5a and 20a episodes for the climate periods centred on 2030, 2050, 2085 with mean low flow discharge at DFS $39 \mathrm{~km}$. The hourly values of V0 (no vegetation) and V100 (full vegetation) are significantly different from STQ in all episodes $(p<0.0001)$.

3.35 and $3.91^{\circ} \mathrm{C}$, the maximum difference was $5.51,4.89$ and $5.51^{\circ} \mathrm{C}$ and the standard deviation of this difference was $0.71,0.66$ and 0.71 for 2030, 2050 and 2085, respectively (Fig. 5a-c).

V0 scenarios were always warmer than STQ scenarios and V100 scenarios were always cooler than the STQ scenarios. The mean differences along the river between V0 and STQ were $1.25,1.26$ and $1.13^{\circ} \mathrm{C}$, the maximum difference was $1.81,1.85$ and $1.66^{\circ} \mathrm{C}$, the standard deviation was 0.35 , 0.36 and 0.32 for 2030,2050 and 2085 , respectively. The mean difference between STQ and V100 was 1.42, 1.52 and $1.26^{\circ} \mathrm{C}$, the maximum difference was $1.92,2.05$ and $1.72{ }^{\circ} \mathrm{C}$, the standard deviation of this difference was $0.46,0.49$ and 0.41 for 2030, 2050 and 2085, respectively (Fig. 5c).
Water temperature was especially sensitive to the removal of vegetation within the first $10 \mathrm{~km}$ (DFS 11-21 km) where there were dense forests which prevented the cool headwaters from warming (Fig. 5d). In this region, temperatures increased by $1.4{ }^{\circ} \mathrm{C}$ under the no-vegetation scenario (V0-STQ). Additional tree cover (V100) caused a temperature reduction of $0.9^{\circ} \mathrm{C}$ compared to the STQ scenario (Fig. 5d). This can be explained by the slower flow velocities in the lower reaches (last $30 \mathrm{~km}-$ DFS $32-62 \mathrm{~km}$ : $\left.0.003 \mathrm{~m} \mathrm{~m}^{-1}, 0.4 \mathrm{~m} \mathrm{~s}^{-1}\right)$ in comparison to the steeper upstream sections (first $10 \mathrm{~km}$ - DFS $11-21 \mathrm{~km}: 0.017 \mathrm{~m} \mathrm{~m}^{-1}$, $0.6 \mathrm{~m} \mathrm{~s}^{-1}$ ), which gives shortwave radiation in unshaded sections more time to heat the water column. For the Pinka, the benefit of additional tree cover maximizing riparian shade became more distinct in the downstream sections (DFS 25- 

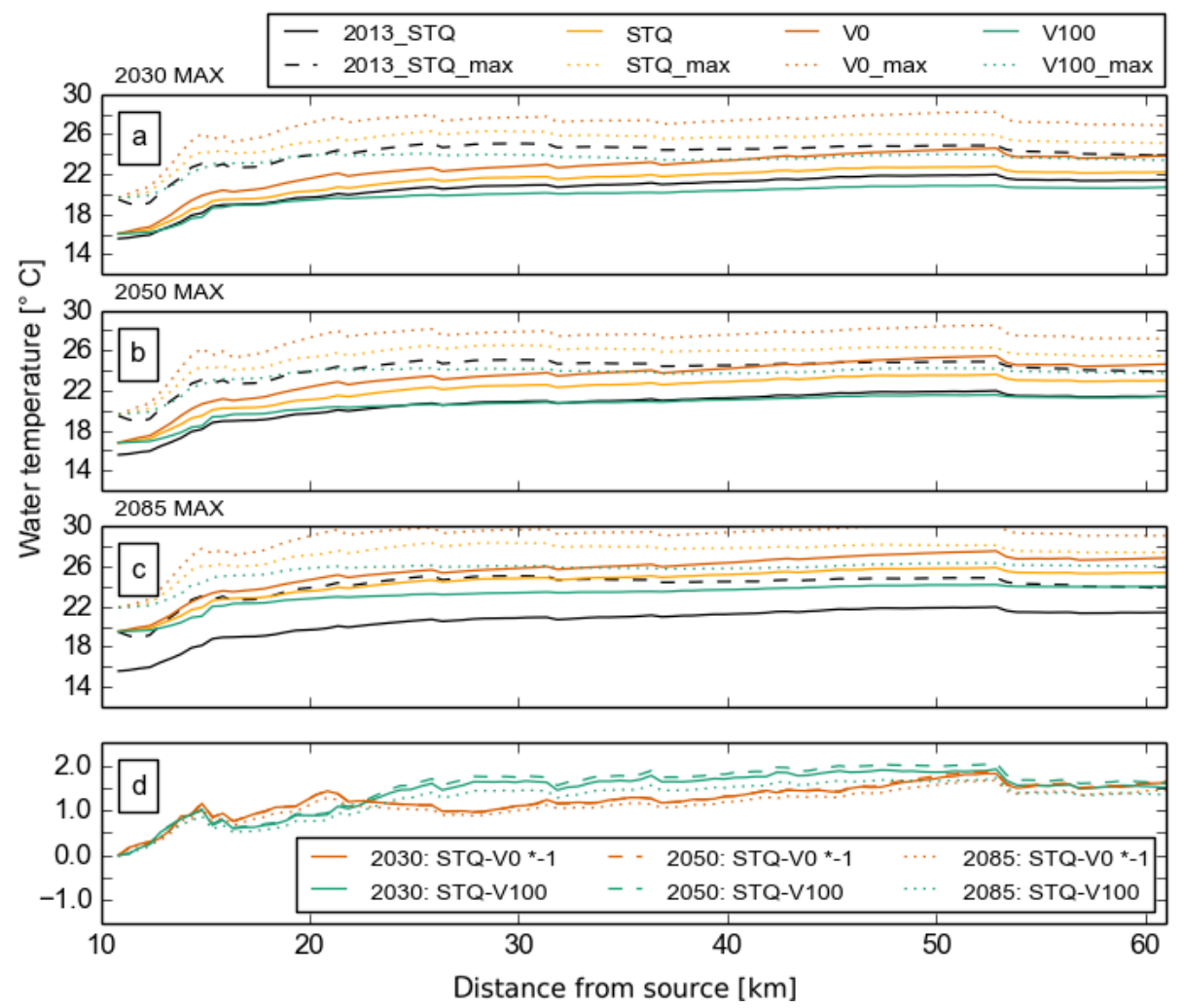

Figure 5. Mean and maximum water temperatures averaged during the maximum events predicted for the climate periods centred on (a) 2030, (b) 2050 and (c) 2085 along the Pinka using vegetation scenarios V0 (no vegetation), STQ and V100 (full vegetation) in comparison to the maximum event recorded in 2013. (d) The difference between STQ and V100 (green) and STQ and V0 (* - 1) (red).

$55 \mathrm{~km}$ ) where the additional tree cover caused a change of $-1.75^{\circ} \mathrm{C}$, while removal only caused a change of around $+1.25^{\circ} \mathrm{C}$ (Fig. 5).

\subsubsection{Diurnal ranges}

For aquatic species, the mean stream temperature is not the only relevant temperature parameter. The daily temperature range, the absolute minima and maxima as well as the timing when extremes take place are of importance as well. These vary along the river and change depending on the different vegetation shade intensities and discharge volumes (Fig. 6). In the contour plot shown in Fig. 6, the warming along the longitudinal gradient is clearly visible, but it is also obvious that the stream is warming to a higher peak each day until the end of the heat episode. In the lower panel of Fig. 6, the daily water temperature amplitude is plotted, along with the energy balance components acting on the river surface for the two locations marked by the black bars in the contour plots. Here, the absolute values, amplitude and timing of extremes can be seen. While the energy balance shows the energy input taking place directly at the location, the water temperature includes the energy input of the whole water volume upstream. An upstream site (DFS $20 \mathrm{~km}$ ) is compared to a downstream site (DSF $61 \mathrm{~km}$ ). They are both open (VTS of V0 $=0.9,1)$ but differ in average water depth $(0.09,0.31 \mathrm{~m})$ and discharge levels $\left(0.34 \mathrm{~m}^{3} \mathrm{~s}^{-1}, 0.8 \mathrm{~m}^{3} \mathrm{~s}^{-1}\right)$.

The daily amplitude of the water temperature is strongly damped by the larger flow volume which can be seen in the comparison of the upstream and downstream sites (Fig. 6). A decrease in discharge of $-15 \%$ can also be seen to affect the daily minima and maxima of stream temperature in open sections (V0). During the V100 scenario, the $15 \%$ discharge reduction has no visible effect $\left(\ll 0.1^{\circ} \mathrm{C}\right)$.

The daily amplitude of the energy fluxes is not affected by flow volume but is reduced by vegetation shade. The hourly values of all energy fluxes are reduced synchronously. Decreased solar input and wind access close to the river surface caused by an increase in vegetation density lowers the energy fluxes. From V0 to V100, the maxima can increase more than $2{ }^{\circ} \mathrm{C}$ (Figs. 6 and 7). However, changes in vegetation density of as little as $20 \%$ can cause an increase of maximum water temperature of more than $0.5^{\circ} \mathrm{C}$ (Fig. 7). A change from, e.g. 100 to $70 \%$ raises the heat input by shortwave radiation $\left(+17 \mathrm{Wm}^{-2}\right)$, convection $\left(+5.6 \mathrm{Wm}^{-2}\right)$ and longwave radiation $\left(+3.7 \mathrm{Wm}^{-2}\right)$ but only increases heat loss by evaporation from the river surface $\left(-21 \mathrm{Wm}^{-2}\right)$ (Fig. 7). The shading affects the maximum as well as the minimum water temperatures and leads to a reduction of the daily amplitude (Figs. 6 

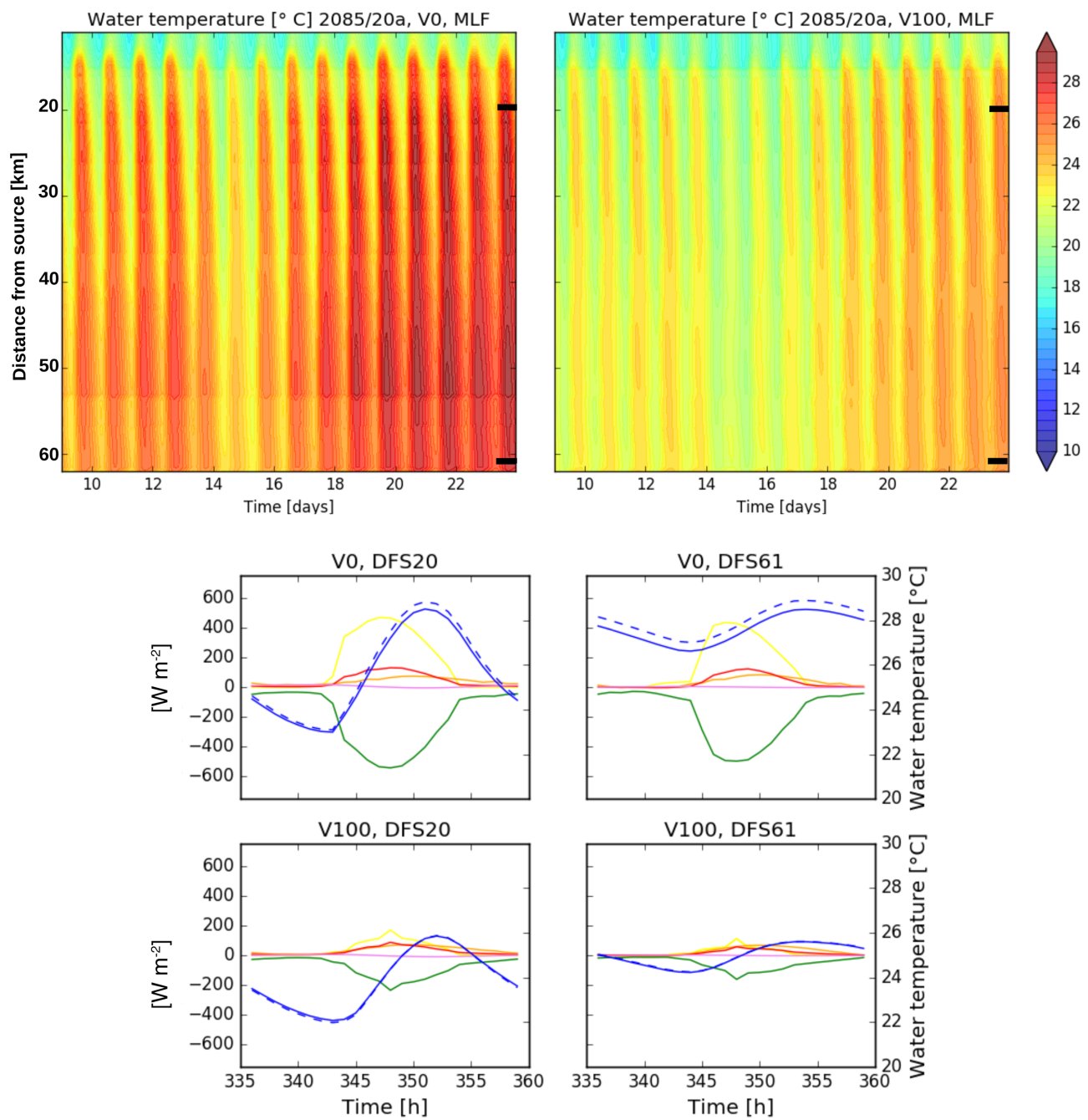

Figure 6. Upper panel: water temperature along the Pinka and the whole 20-year return period event centred on 2085 for no vegetation (V0) and full vegetation (V100). The black lines mark the location of the data shown below. Lower panel: the effect of a $15 \%$ discharge reduction (MLF of $15 \%$ ) of the mean low flow conditions (blue, dashed) on stream temperature compared to MLF (blue, solid) and the diurnal amplitude of all energy fluxes (shortwave radiation balance is yellow, latent heat flux is green, longwave radiation balance is red, sensible heat flux is orange and conduction heat flux is violet) for an upstream (DFS $20 \mathrm{~km}$ ) location and a downstream (DFS $61 \mathrm{~km}$ ) location for the 20-year return period event centred on 2085 for no vegetation (V0) and maximum vegetation (V100).

and 7). An interesting aspect is that the peak of stream temperature occurs about $1 \mathrm{~h}$ later when vegetation is included. With a vegetation density reduction of $50 \%$ (VD50), the diurnal range and especially the maximum temperatures are further increased (Fig. 7). It is interesting to note that halving vegetation height has a similar or less significant effect as reducing vegetation density by $20 \%$ (Fig. 7).

\subsubsection{Trends}

The trend lines were calculated by minimizing the square error. An ANCOVA (analysis of covariance) showed significant interactions between vegetation and air temperature $(p<0.001)$. The equal slope assumption failed; the equal variance test was passed. Mean, maximum and minimum stream temperatures increase as air temperature increases (Fig. 8). Under the assumption of full vegetation, the intercept of the regression line is lowest for the mean and maxima, while under the assumption of no vegetation it is lowest for the minima. The difference between the vegetation scenarios is greatest for the maxima and smallest for the minima. The slope, on the other hand, is smallest for the maxima and greatest for the minima. All scenarios and values show a squared Spearman's rank correlation coefficient between 0.78 and 0.93 . For mean and maximum temperatures, the trend line of V0 is steeper than that of V100 $(17 \%)$, which means that, supposing no vegetation, the maximum temperatures will increase at a higher rate. For the daily minima, the difference in slope is even greater $(30 \%)$. The regres- 

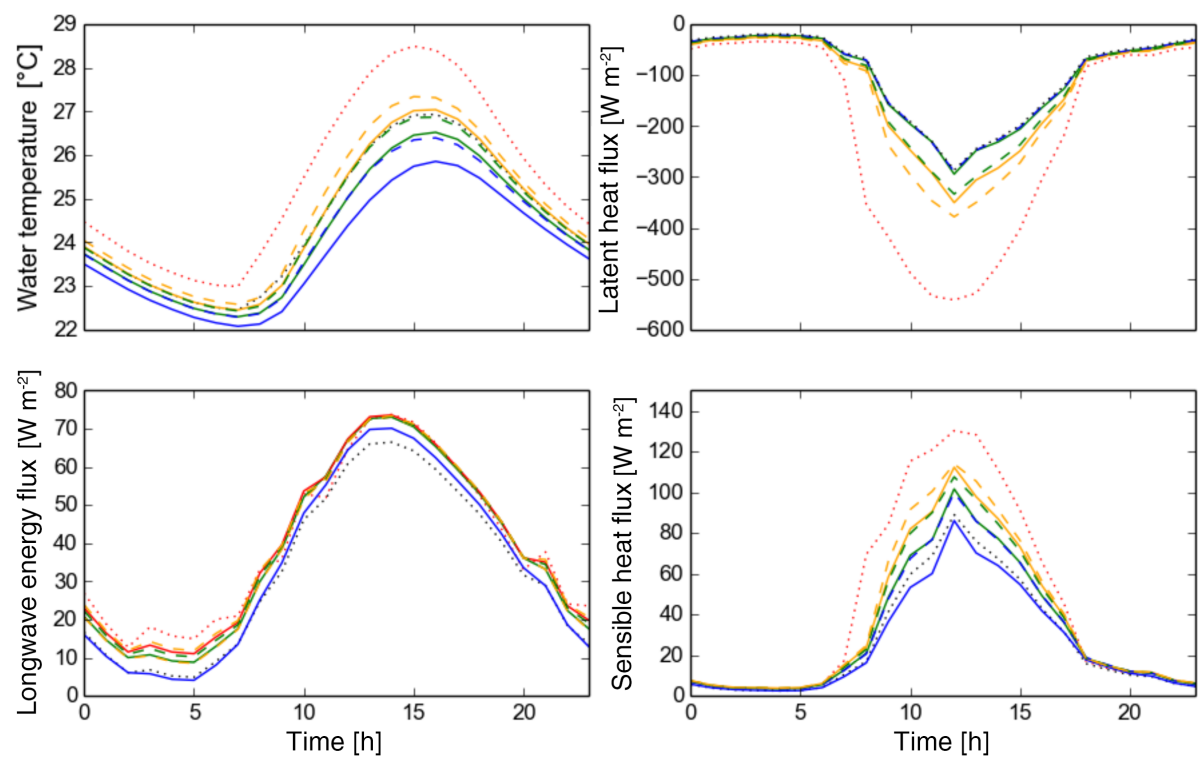

\begin{tabular}{|llllll}
- & VD90, VH100 & - & VD70, VH100 & - & VD50, VH100 \\
-- & VD90, VH50 & -- & VD70, VH50 & -- & VD50, VH50 \\
$\cdots .$. & STQ & $\cdots .$. & V0
\end{tabular}

Figure 7. The effect of the vegetation scenarios of maximum vegetation height (VH100) and $50 \%$ vegetation height (VH50), natural dense vegetation (VD90), natural light vegetation (VD70), sparse vegetation (VD50), V0 (no vegetation) and STQ (actual vegetation) on the diurnal amplitude of water temperature and the air-temperature-dependent energy fluxes longwave radiation, sensible and latent heat fluxes for the 20 -year return period events of the final day of the climate periods centred on 2085 for mean low flow conditions (MLF) for an upstream location (DFS $20 \mathrm{~km}$ ).

sion lines of the halved vegetation height scenario (V50) and the reduced vegetation density scenario (V70) cross for minima, mean and maxima values. The change in slope though is small (3.6, 1.4 and $5.8 \%$ for the mean, minima and maxima, respectively) and statistically not significant.

\section{Discussion}

\subsection{Energy fluxes during heat waves}

In the present article, evaporative heat flux was responsible for $100 \%$ of heat loss from river water on average. Shortwave radiation balance, longwave radiation balance and sensible heat flux were 64,11 and $25 \%$ of the total energy input, respectively.

During summer periods of high air temperature, the difference between air and water temperature increases, which can trigger intensified evaporative flux that cools the river but can also cause sensible heat flux to heat the water column (Benyahya et al., 2012). Benyahya et al. (2012) found that evaporative heat flux accounted for $100 \%$ of energy outputs during 7-23 June 2008 while shortwave radiation balance, longwave radiation balance and sensible heat flux were $72.53,24.05$ and $2.03 \%$ of the energy input, respectively.

\subsection{Magnitude of stream temperature rise}

The modelled 20-year return period heat wave (20a) in the climate period $2071-2100$ showed a $+3.8^{\circ} \mathrm{C}$ increase in air temperature with respect to the observed period. Increases in maximum, mean and minimum stream temperatures of close to $+3{ }^{\circ} \mathrm{C}$ with respect to the observed period were simulated for this episode. During the Max event, the modelled increases of maximum, mean and minimum temperatures were $3.4^{\circ} \mathrm{C}, 3.5$ and $4{ }^{\circ} \mathrm{C}$, respectively. When looking at the whole river, mean changes of $3.3^{\circ} \mathrm{C}$ for the maximum and $3.9^{\circ} \mathrm{C}$ mean temperatures were calculated. Melcher et al. (2014) also found that average and maximum temperatures show similar warming trends. An increase of $3.9^{\circ} \mathrm{C}$ from the OBS period to 2085 corresponds to an increase of $0.43^{\circ} \mathrm{C}$ decade ${ }^{-1}$. An increase of $3^{\circ} \mathrm{C}$ equates to an increase of $0.33^{\circ} \mathrm{C}$ decade $^{-1}$.

The relatively low values of water temperature predicted for the 20a 2050 heat wave might be explained by higher wind speeds and lower air humidity causing higher evaporation rates and lower solar radiation energy input compared to 2013. The relatively low modelled temperatures were most evident in maximum water temperatures. For the V0 scenario, relatively low water temperatures were also predicted, which was caused by increased evaporation. The maximum 

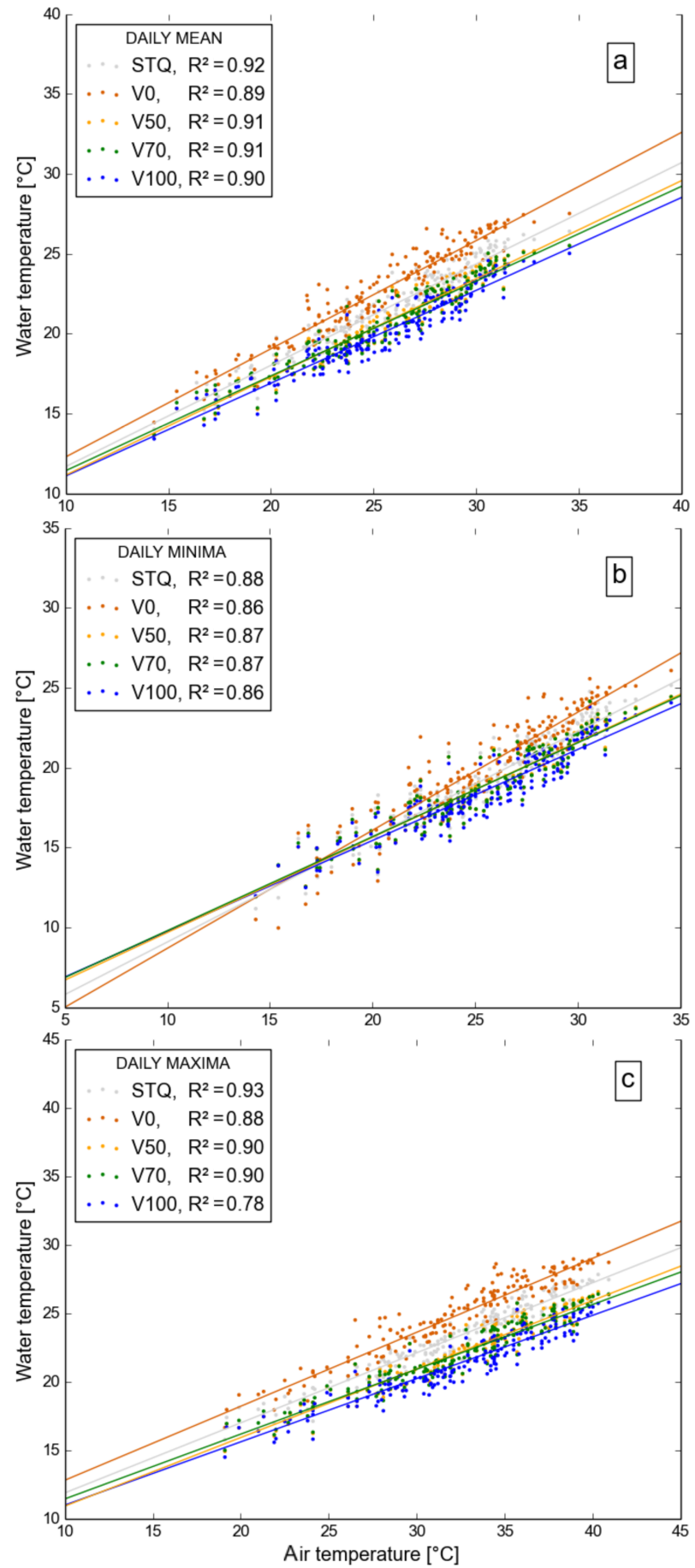

Figure 8. Correlations between water temperature and the daily (a) mean, (b) minima and (c) maxima air temperatures for the 1a, 5a, 20a and Max episodes of the climate periods centred at 2030, 2050 and 2085 for existing vegetation (STQ), no vegetation (V0), vegetation height of $50 \%$ (V50), vegetation of $70 \%$ density (V70) and full vegetation (V100) reported with the squared Spearman rank correlation coefficient. ANCOVA showed significant interactions between vegetation and air temperature $(p<0.001)$. vegetation scenario (V100) shows similar stream temperatures to 2013.

Temperature increase in Austrian stream waters is well documented and ubiquitous. All 230 stations of the Austrian hydrographic central office, with different elevations, distances from source and catchment areas recorded increases of stream temperature of an average of $1.5^{\circ} \mathrm{C}$ $\left(0.48^{\circ} \mathrm{C} \mathrm{decade}^{-1}\right)$ from 1980 to 2011 (BMLFUW, 2011). The data were elevation corrected using external drift top kriging (Skøien et al., 2006) and a mean trend was calculated using the Mann-Kendall test (Burn and Hag Elnur, 2002). Melcher et al. (2013) analysed 60 stations and found a similar trend of $1{ }^{\circ} \mathrm{C}$ within the last 35 years for mean August temperatures, which was independent of the river type $\left(0.29^{\circ} \mathrm{C}\right.$ decade $\left.^{-1}\right)$. The annual mean temperature of the Danube has been rising (Webb and Nobilis, 1995) and is likely to continue to rise to reach a value between 11.1 and $12.2^{\circ} \mathrm{C}$ by 2050 compared to around $9^{\circ} \mathrm{C}$ at the beginning of the 20th century at the border with Slovakia (Nachtnebel et al., 2014). Dokulil (2013) extrapolated the quadratic regression of the period 1900-2006 of the Danube near Vienna and predicted an increase of up to $3.2{ }^{\circ} \mathrm{C}$ by 2050 with respect to $1900\left(0.21^{\circ} \mathrm{C}\right.$ decade $\left.^{-1}\right)$. Using linear regression, the increase was only $2.3^{\circ} \mathrm{C}\left(0.15^{\circ} \mathrm{C}\right.$ decade $\left.^{-1}\right)$, but using the linear trend beginning from 1970 , the increase was $3.4^{\circ} \mathrm{C}$ $\left(0.23^{\circ} \mathrm{Cdecade}^{-1}\right)$. Due to the size of the Danube, daily amplitudes and extremes are not comparable to the Pinka, but trends in mean water temperature values are comparable though. The temperature values predicted by this study were clearly greater than the model uncertainty and lie in the upper region of the values published by other studies (BMLFUW, 2001; Dokulil, 2013; Melcher et al., 2013, 2014).

Considering a likely discharge decrease (Nachnebel et al., 2014), a slightly higher temperature rise might be expected. Van Vliet et al. (2011) analysed 157 river temperature stations globally for the 1980-1999 period and predicted increases of annual mean river temperature of $1.3,2.6$ and $3.8^{\circ} \mathrm{C}$ under air temperature increases of 2,4 and $5^{\circ} \mathrm{C}$, respectively. Discharge decreases of 20 and $40 \%$ increased the modelled water temperature rises by 0.3 and $0.8^{\circ} \mathrm{C}$ on average (Van Vliet et al., 2011).

\subsection{Ability of riparian vegetation to mitigate the expected stream temperature rise}

How will riparian vegetation systems behave in the future? What are the feedback mechanisms of increased shading under a warmer heat wave scenario? Decrease in discharge caused by increased evaporation from the river surfaces caused by missing riparian vegetation (V0 compared to V100) was calculated to be $-0.001 \mathrm{~m}^{3} \mathrm{~s}^{-1}$ at the lower boundary of the river (DFS $61 \mathrm{~km}$ ). Also, during an MLF reduced by $15 \%$, the loss of water to evaporation was only $-0.001 \mathrm{~m}^{3} \mathrm{~s}^{-1}$. Therefore, mass loss was not found to be a significant driver of temperature rise in a river of this size. 
Further, there might be a potential decrease of discharge caused by increased withdrawal of river water by the riparian vegetation under warmer climates. As species of the floodplain forest are "spender"-type plants that do not economize their water use, this needs to be considered. In this study, a simulation is included with a discharge decrease of $15 \%$, a level that is presently expected from past observations. This estimation includes precipitation losses as well as increased evapotranspiration by the soil-vegetation system of the catchment area and increased evapotranspiration by the riparian vegetation via rises in air temperature. Different discharge scenarios were not simulated for all episodes, because whether a low flow situation was considered or not was more dominant than the reduction expected by climate change.

The increased air humidity and reduced air temperature caused by transpiration of riparian vegetation close to the river reduce air humidity and air temperature gradients. The effect on water temperature was calculated to be a maximum of around $0.2^{\circ} \mathrm{C}$. More directly, vegetation affects water temperature by reducing shortwave radiation input, but also it reduces the view to sky which affects longwave radiation balance and the turbulent heat fluxes. Community changes which might affect vegetation height and density are possible within the next century, though changes in vegetation height and density in floodplain forests in natural systems are mainly due to succession. Primack (2000), Garssen et al. (2014) and Rivaes et al. (2014) studied the effect of climate change on natural riparian vegetation cover via changes in the hydrological regime including inundation periods and intensity, days since rain and the decline of water table. As the Pinka is anthropogenically influenced and will be regulated for the foreseeable future, no dynamical changes and no natural succession dynamics are expected which could cause an extreme change in vegetation cover.

Different vegetation scenarios were simulated in this study to quantify the potential effects of shading and wind reduction caused by vegetation. Compared to the status quo (STQ) scenario, additional riparian vegetation (V100) could reduce maximum stream temperatures during extreme heat waves by $2.2^{\circ} \mathrm{C}$, mean temperatures by $1.6^{\circ} \mathrm{C}$ and minimum temperatures by $0.9^{\circ} \mathrm{C}$ (Table 4). Removal of existing vegetation (V0) amplified stream temperature increases and could cause an average increase of maximum, mean and minimum stream temperatures of $1.8,1.3$ and $1.0^{\circ} \mathrm{C}$, respectively, in comparison with the STQ vegetation scenario (Table 4).

Removal of vegetation (V0) magnified stream temperatures during 20-year return period events by the end of the century by up to 4.2 (mean) and $4.5^{\circ} \mathrm{C}$ (daily maximum). Additional riparian vegetation (V100), on the other hand, mitigated part of the rise in maximum temperatures, so there was only a $1.1{ }^{\circ} \mathrm{C}$ increase. Although the increase of mean temperatures was reduced to about $1.4^{\circ} \mathrm{C}$, riparian vegetation management alone was not enough to compensate for the predicted warming caused by climate change. The water temperature reduction rates predicted in the present article lie within the range of observed changes of pre- and postharvest situations found in the literature (Cole and Newton, 2013; Moore et al., 2005).

The maximum water temperatures during heat waves in particular could be reduced significantly by vegetation shade. Daily mean and daily maximum temperatures tend to increase more strongly for higher air temperatures if less vegetation is present. Daily minimum temperatures increase at an even higher rate. These trends are in agreement with findings about experimental data analysed by Kalny et al. (2017).

Vegetation height and density can alter the slope of the temperature trend line. For example, with dense low vegetation, water temperature starts lower and ends higher for the same air temperature compared to the high vegetation and less dense scenario, which indicates that there is some impeding of cooling during the night by lower vegetation compared to higher vegetation. Water temperatures rise more rapidly for dense low vegetation than high vegetation of reduced density. High vegetation of lower density cannot compete with dense high vegetation in terms of reduction of stream water temperature though.

During heat wave situations, the reduction in air exchange causes an important lag in temperature rise, so the time of maximum solar exposure does not coincide with the maximum heat stress caused by water temperature. This lag is known in the literature (Brown and Krygier, 1970). Apart from its influence on stream temperature, vegetation can cast spatially differentiated shade, which results in areas of different Sun exposure and energy balance. This heterogeneity can provide ecological niches which are important for different development stages of river fauna (Clark et al., 1999).

\subsection{Limitations}

Vegetation mainly causes lower maximum stream temperatures by reducing the solar radiation input at the river surface by shading. This effect is strong during times of clear skies and high solar irradiation. Under cloudy conditions, this effect is less pronounced, and during nighttime it is absent, but outgoing longwave radiation is still impeded. This in turn could lead to higher mean and minimum temperatures, which can be also seen in the simulated low global radiation scenarios.

Although vegetation can have important effects on stream temperature, there will be river sections which will not be affected by the addition (or removal) of vegetation due to upstream or lateral, surface or subsurface advection of heat or topographic shade (Johnson and Wilby, 2015). Groundwater influence was not measured and no groundwater influence was assumed in the model. Although the model performed well (RMSE of $0.88^{\circ} \mathrm{C}$ ) there might be some groundwater influence between DFS 45 and $55 \mathrm{~km}$ where the measurements lie below the simulation results. Other possible future alterations to the river via development or climate change were not considered here. These include potential anthro- 
pogenic heat sources or sinks like discharges of tempered waste water, possible changes in stream velocity and shading, sediment changes caused by impoundments, regulation and canalization, or discharge changes such as withdrawal of water for irrigation. The climate input used only one possible emission scenario simulated by one regional climate model. The percentage contributions of surface, subsurface, groundwater and/or snowmelt still have to be analysed in more detail (Johnson and Wilby, 2015). Apart from rising air temperatures and discharge changes, anthropogenic influences like discharges from waste water treatment plants and cooling water can influence stream temperatures in a negative way and are therefore presently illegal in Austria (WRG, 1959). Other possible consequences of climate change are changes in sediment loads in river systems due to changes in mobilization, transport and deposition of sediment, which is expected to be very likely (APCC, 2014). Sediment changes might alter the bed conduction flow as well as flow velocity, which can influence the magnitude and variability of stream temperature. Artificial changes which deteriorate the situation are presently illegal in Austria as well (WRG, 1959).

\section{Conclusions}

In this study, the influence of expected changes in heat wave intensity during the 21 st century on stream temperature in the rithron to upper potamal section of the human-impacted eastern Austrian Pinka was simulated and the mitigating effect of riparian vegetation shade on the radiant and turbulent energy fluxes was analysed. By the end of the century (20712100), in the study region, an air temperature increase of 3.8 to $5.6^{\circ} \mathrm{C}$ was predicted during annual or less frequent extreme heat waves in comparison to the observed period of 1981-2010. Stream water temperature increases of less than $1.5^{\circ} \mathrm{C}$ were modelled for the first half of the century. For the period 2071-2100, a more significant increase of $3{ }^{\circ} \mathrm{C}$ in maximum, mean and minimum stream temperatures was predicted for a 20-year return period heat event.

Discharge changes, caused by increased evaporation due reduced shade, were not found to be significant. Discharge changes caused by precipitation and increased evapotranspiration in the catchment area as expected from past observations was found to be insignificant compared to the changes caused by vegetation shade.

Vegetation could reduce stream temperature during heat waves when conditions of high solar radiation predominate. Even when maximum vegetation extent with maximum height and density including plantations and replacement plantings was assumed, the additional riparian vegetation was not able to fully mitigate the expected temperature rise caused by climate change. However, during extreme heat waves, maximum stream temperatures could be reduced by $2.2^{\circ} \mathrm{C}$ and mean temperatures by $1.6^{\circ} \mathrm{C}$. Removal of existing vegetation amplified stream temperature increases and could cause an increase of maximum and mean stream temperatures by 1.8 and $1.3^{\circ} \mathrm{C}$, respectively, in comparison with the status quo vegetation scenario. With complete vegetation removal, maximum stream temperatures in annual heat events at the end of the century could increase by more than $4{ }^{\circ} \mathrm{C}$ compared to the present time.

Daily amplitudes were reduced by riparian vegetation and the timing of the peak temperature was delayed by about $1 \mathrm{~h}$. A reduction of vegetation density by $20 \%$ had shown a similar effect as a $50 \%$ reduction of vegetation height. Vegetation can reduce maximum temperatures more effectively on an absolute scale but also reduced the trends significantly compared to the no-vegetation scenario. Minimum temperatures increased most.

This study shows that it is very likely that during extreme events a temperature increase of $2^{\circ} \mathrm{C}$ will be exceeded during this century. This is the magnitude of the temperature differentiation of fish zones and in particular for the occurrence of native cold-water-preferring and warm-water-preferring fish species (Logez et al., 2013; Melcher et al., 2013; Pletterbauer et al., 2015). At a stream temperature of $20^{\circ} \mathrm{C}$, cold-wateradapted species begin to experience temperature-induced mortality (Melcher et al., 2014; Schaufler 2015). During a simulated annual heat wave event in the period 2016-2035, this threshold was never exceeded in the most upstream region (DFS $13 \mathrm{~km}$ ), which is presently populated by the coldadapted species brown trout (Guldenschuh 2015). At the end of the century, during a heat wave event of a 20-year return period, the threshold was likely to be exceeded for 72 of $120 \mathrm{~h}$. At the lower boundary of the trout zone (DFS $20 \mathrm{~km}$ ), the $20^{\circ} \mathrm{C}$ mark was exceeded for 70 of the $120 \mathrm{~h}$ during heat waves at the beginning of the century, but riparian vegetation shade could reduce this period to $9 \mathrm{~h}$ in total. The mitigation possibilities of vegetation were limited though and could not fully compensate for the whole predicted temperature raise. At the end of the century, in heat waves of a 5-year or shorter return period, even if maximum vegetation was assumed, $20^{\circ} \mathrm{C}$ was exceeded during the whole heat wave event.

Global warming has multiple impacts on changes in aquatic ecosystems, whereas in combination with loss of habitat and other human pressures, this is leading to a deadly anthropogenic-induced cocktail (Schinegger et al., 2011). The study affirmed the importance of shading and riparian vegetation along river banks for aquatic biodiversity and indicates the added value of riparian vegetation to mitigate climate change effects on water temperature. During this study, no economic evaluation of the vegetation scenarios could be done. While maximum vegetation height and densities of $50 \%$ can easily be reached without external efforts, this process can certainly be accelerated as well as high densities assured by planting additional trees. This comes at a certain cost, but it might be worth it to invest. The used method provides a model for weighting of interactions of environmental parameters especially during heat wave events. The find- 
ings and recommendations gained with this methodology can help key decision makers in choosing the right restoration measures. The study in general emphasizes the importance of land-water interfaces and their ecological functioning in aquatic environments. 


\section{Appendix A}

\begin{tabular}{ll} 
Abbreviations & \\
\hline DFS & distance from source \\
INCA & integrated nowcasting through comprehensive analysis \\
VTS & view to sky
\end{tabular}

Climate episodes

1a, 5a, 20a

Max

OBS

2030, 2050, 2085

episodes of 1-, 5-, 20-year return periods within a 30-year climate period

maximum event of a 30-year climate period

observed period (1981-2010)

30-year climate period centred on 2030 (2016-2045), 2050 (2036-2065), 2085 (2071-2100)

Discharge scenarios

\begin{tabular}{ll}
\hline MLF & mean low flow of the gauging station at DFS $13 \mathrm{~km}: 0.143 \mathrm{~m}^{3} \mathrm{~s}^{-1}$, DFS $62 \mathrm{~km}: 0.795 \mathrm{~m}^{3} \mathrm{~s}^{-1}$ \\
MLF-15 & MLF minus 15\% discharge \\
\hline Vegetation scenarios & \\
\hline STQ & "status quo", existing/actual vegetation \\
V100 & "maximum vegetation" - vegetation height $30 \mathrm{~m}$, vegetation density $90 \%$ (VD90, VH100) \\
V70 & "reduced density" - vegetation height $30 \mathrm{~m}$, vegetation density $70 \%$ (VD70, VH100) \\
V50 & "intermediate vegetation height" - vegetation height $15 \mathrm{~m}$, vegetation density 90\% (VD90, VH50) \\
V0 & "no vegetation" \\
VD50, VH100 & vegetation density $50 \%$, vegetation height $100 \%(30 \mathrm{~m})$ \\
VD70, VH50 & vegetation density $70 \%$, vegetation height $50 \%(15 \mathrm{~m})$ \\
VD50, VH50 & vegetation density $50 \%$, vegetation height $50 \%(15 \mathrm{~m})$
\end{tabular}


Code availability. The last official version of Heat Source software used is available online at http://www.oregon.gov/deq/wq/tmdls/ Pages/TMDLs-Tools.aspx. The changes included in Heat Source within this study will be implemented in the next version, which will be available at the same location.

Data availability. The simulation input and result data sets for the present and future heat wave episodes used in this article are published on the freshwater biodiversity data portal (https://doi. org/10.13148/BFFWM8). As they are part of the research project BIO_CLIC, the metadata are published together with the other vegetation, morphological and biological data sets produced in the project in the Freshwater Metadata Journal (https://doi.org/10. 15504/fmj.2017.22).

Author contributions. AM was in charge of the hydrobiological aspects. PW helped to better understand the energy fluxes of the riverine system. HF selected the climate episodes and helped to interpret the significance of the results. LD produced the climate episode data and the upstream boundary water temperature. GK organized the field campaigns and helped Valeria Ledochowski to build the basic vegetation and morphology data set. HT organized and executed the water temperature measurements further processed the all input data for the use of Heat Source, adapted and validated the model. She ran the Heat Source simulations for all selected episodes and prepared the manuscript.

Competing interests. The authors declare that they have no conflict of interest.

Acknowledgements. This research was part of the project BIO_CLIC and LOWFLOW+ both funded within the Austrian Climate Research Programme (ACRP) by the Klima und Energiefond. The regional climate model data sets used to produce the climate episodes were developed in the ENSEMBLES project supported by the European Commission's Sixth Framework Programme through contract GOCE-CT-2003-505539. The INCA data set was created by the Zentralanstalt für Meteorologie und Geodynamik (ZAMG). Hydrological data and the digital elevation model were provided by hydrographic services, which are part of the Federal Ministry of Agriculture, Forestry, Environment and Water management and the federal state governmental geoinformation service authorities of Styria and Burgenland. Bernhard Spangl from the Institute of Applied Statistics and Computing (IASCBOKU) gave advice regarding statistics. Special thanks are given to the Oregon Department of Environmental Quality, who maintain the Heat Source model and opened the source code for scientific use.

Edited by: Anas Ghadouani

Reviewed by: four anonymous referees

\section{References}

Ahrens, B., Formayer, H., Gobiet, A., Heinrich, M., Hofstätter, M., Matulla, C., Prein, A. F., and Truhetz, H.: Zukünftige Klimaentwicklung/Future Climate Developments, in: Österreichischer Sachstandsbericht Klimawandel 2014 (AAR14), Austrian Panel on Climate Change (APCC), Verlag der Österreichischen Akademie der Wissenschaften, Wien, Österreich, 301-346, 2014.

APCC: Österreichischer Sachstandsbericht Klimawandel 2014 (AAR14), Herausgeber: Kromp-Kolb, H., Nakicenovic, N., Steininger, K., Gobiet, A., Formayer, H., Köppl, A., Prettenthaler, F., Stötter, J., and Schneider, J., Verlag der Österreichischen Akademie der Wissenschaften, Wien, Österreich, 1096 pp., 2014.

Arismendi, I., Safeeq, M., Dunham, J. B., and Johnson, S. L.: Can air temperature be used to project influences of climate change on stream temperature?, Environ. Res. Lett., 9, 084015, https://doi.org/10.1088/1748-9326/9/8/084015, 2014.

Auer, I., Böhm, R., Jurkovic, A., Lipa, W., Orlik, A., Potzmann, R., Schöner, W., Ungersböck, M., Matulla, C., Briffa, K., Jones, P., Efthymiadis, D., Brunetti, M., Nanni, T., Maugeri, M., Mercalli, L., Mestre, O., Moisselin, J.-M., Begert, M., MüllerWestermeier, G., Kveton, V., Bochnicek, O., Stastny, P., Lapin, M., Szalai, S., Szentimrey, T., Cegnar, T., Dolinar, M., GajicCapka, M., Zaninovic, K., Majstorovic, Z., and Nieplova, E.: HISTALP - historical instrumental climatological surface time series of the Greater Alpine Region, Int. J. Climatol., 27, 17-46, https://doi.org/10.1002/joc.1377, 2007.

Auer, I., Foelsche, U., Böhm, R., Chimani, B., Haimberger, L., Kerschner, H., Koinig, K. A., Nicolussi, K., and Spötl, C.: Vergangene Klimaänderung in Österreich, in: Österreichischer Sachstandsbericht Klimawandel 2014 (AAR14), Austrian Panel on Climate Change (APCC), Verlag der Österreichischen Akademie der Wissenschaften, Wien, Österreich, 227-300, 2014.

Beniston, M., Stephenson, D. B., Christensen, O. B., Ferro, C. A. T., Frei, C., Goyette, S., Halsnaes, K., Holt, T., Jylhä, K., Koffi, B., Palutikof, J., Schöll, R., Semmler, T., and Woth, K.: Future extreme events in European climate: an exploration of regional climate model projections, Climatic Change, 81, 71-95, https://doi.org/10.1007/s10584-006-9226-z, 2007.

Benyahya, L., Caissie, D., Satish, M. G., and El-Jabi, N.: Longwave radiation and heat flux estimates within a small tributary in Catamaran Brook (New Brunswick, Canada), Hydrol. Process., 26, 475-484, 2012.

Birkel, I. and Mayer, A.: Ökologische Zusammenfassung der Flussauen an Iller, Lech, Isar, Salzach und Donau und ihre Unterschutzstellung, Bayrisches Landesamt für Umweltschutz, München, 1992.

Bloisa, J. L., Williams, J. W., Fitzpatrick M. C., Jackson, S. T., and Ferrierd, S.: Space can substitute for time in predicting climatechange effects on biodiversity, P. Natl. Acad. Sci. USA, 110, 9374-9379, 2013.

BMLFUW: Bundesministerium für Land- und Forstwirtschaft, Umwelt und Wasserwirtschaft, Herausgeber: Schöner, W., Böhm, R., Haslinger, K., Blöschl, G., Kroiß, H., Merz, R., Blaschke, A. P., Viglione, A., Parajka, J., Salinas, J. L., Drabek, U., Laaha, G., and Kreuzinger, N.: Anpassungsstrategien an den Klimawandel für Österreichs Wasserwirtschaft, Studie der Zen- 
tralanstalt für Meteorologie und Geodynamik und der Technischen Universität Wien, Wien, 486 pp., 2011.

BMLFUW: Abteilung I/4 - Wasserhaushalt, Hydrographisches Jahrbuch von Österreich 2013, Wien, 2015.

Böhm, R.: ALP-IMP (EVK-CT-2002-00148) Multi-centennial climate variability in the Alps based on Instrumental data, Model simulations and Proxy data, final report for RTD-project, ZAMG, Central Institute for Meteorology and Geodynamics, Vienna, Austria, 2006.

Böhm, R.: Changes of regional climate variability in central Europe during the past 250 years, Eur. Phys. J. Plus, 127, 13 pp., https://doi.org/10.1140/epjp/i2012-12054-6, 2012.

Böhm, R., Auer, I., Schöner, W., Ganekind, M., Gruber, C., Jurkovic, A., Orlik, A., and Ungersböck, M.: Eine neue Webseite mit instrumentellen Qualitäts-Klimadaten für den Grossraum Alpen zurück bis 1760, Wiener Mitteilungen Band 216: Hochwässer: Bemessung, Risikoanalyse und Vorhersage, 2009.

Boyd, M. and Kasper, B.: Analytical methods for dynamic open channel heat and mass transfer: Methodology for heat source model Version 7.0, available at: http://www.deq.state.or.us/wg/ TMDLs/tools.htm (last access: 11 January 2018), 2003.

Brown, G. W. and Krygier, J. T.: Effects of Clear-Cutting on Stream Temperature, Water Resour. Res., 6, 1133-1139, 1970.

Burn, D. H. and Hag Elnur, M. A.: Detection of hydrologic trends and variability, J. Hydrol., 255, 107-122, 2002.

Caissie, D.: The thermal regime of rivers: a review, Freshw. Biol., 51, 1389-1406, https://doi.org/10.1111/j.13652427.2006.01597.x, 2006.

Caissie, D., Nassir, E.-J., and Mysore, G. S.: Modelling of maximum daily water temperatures in a small stream using air temperatures, J. Hydol., 251, 14-28, 2001.

Caissie, D., Satish, M. G., and El-Jabi, N.: Predicting water temperatures using a deterministic model: Application on Miramichi River catchments (New Brunswick, Canada), J. Hydrol., 336, 303-315, 2007.

Capon, S. J., Chambers, L. E., Mac Nally, R., Naiman, R. J., Davies, P., Marshall, N., Pittock, J., Reid, M., Capon, T., Douglas, M., Catford, J., Baldwin, D. S., Stewardson, M., Roberts, J., Parsons, M., and Williams, S. E.: Riparian Ecosystems in the 21st Century: Hotspots for Climate Change Adaptation?, Ecosystems, 16, 359-381, https://doi.org/10.1007/s10021-013-9656-1, 2013.

Chen, J., Franklin, J. F., and Spies, T. A.: Contrasting microclimates among clearcut, edge, and interior of old-growth Douglas-fir forest, Agr. Forest Meteorol., 63, 219-237, 1993.

Clark, E., Webb, B. W., and Ladle, M.: Microthermal gradients and ecological implications in Dorset rivers, Hydrol. Process., 13, 423-438, 1999.

Cluis, D.: Relationship between stream water temperature and ambient air temperature - A simple autoregressive model for mean daily stream water temperature fluctuations, Nord. Hydrol., 3, 65-71, 1972.

Cole, E. and Newton, M.: Influence of streamside buffers on stream temperature response following clear-cut harvesting in western Oregon, Can. J. Forest Res., 43, 993-1005, 2013.

Davies-Colley, R. J. and Quinn, J. M.: Stream lighting in five regions of North Island, New Zealand: Control by channel size and riparian vegetation, New Zeal. J. Mar. Fresh., 32, 591-605, https://doi.org/10.1080/00288330.1998.9516847, 1998.
Déqué, M.: Frequency of precipitation and temperature extremes over france in an anthropogenic scenario: model results and statistical correction according to observed values, Glob. Planet. Change, 57, 16-26, 2007.

Déqué, M., Dreveton, C., Braun, A., and Carilolle, D.: The ARPEGE/IFS atmosphere model: a contribution to the French community climate modelling, Clim. Dynam., 10, 249-266, https://doi.org/10.1007/BF00208992, 1994.

Dokulil, M. T.: Impact of climate warming on European inland waters, Inland Waters, 4, 27-40, https://doi.org/10.5268/IW4.1.705, 2013.

Dossi, F., Leitner, P., Steindl, E., and Graf, W.: Der Einfluss der Wassertemperatur auf die benthische Evertebratenzönose in mittelgrossen Fliessgewässern am Beispiel der Flüsse Lafnitz und Pinka (Burgendland, Steiermark) in Österreich, Mitteilungsblatt für die Mitglieder des Vereins für Ingenieurbiologie, Ingenieurbiologie: Neue Entwicklungen an Fließgewässern, Hängen und Böschungen, 1, 22-28, 2015.

Egger, G., Drescher, A., Hohensinner, S., and Jungwirth, M.: Riparian vegetation model of Danube River (Machland, Austria): changes of processes and vegetation patterns, Conference $\mathrm{Pa}$ per at the 6th International Symposium on Ecohydraulics, New Zealand, 18-23 February 2007.

Ellenberg, H. and Leuschner, H: Vegetation Mitteleuropas mit den Alpen, 6. Auflage, Verlag Eugen Ulmer, Stuttgart, XXIV + 1134 pp., 2012.

Erickson, T. R. and Stefan, H. G: Linear Air/Water Temperature Correlations For Streams During Open Water Periods, Journal of Hydrologic Engineering, July 2000, St. Anthony Falls Laboratory Technical Paper No. 604, Series A, 317-321, 2000.

Garner, C.: Modeling the Effect of Riparian Shading on Water Temperature for Portions of the Carson River, Thesis, University of Nevada, Reno, USA, 2007.

Garner, G., Malcolm, I. A., Sadler, J. P., and Hannah, D. M.: What causes cooling water temperature gradients in a forested stream reach?, Hydrol. Earth Syst. Sci., 18, 5361-5376, https://doi.org/10.5194/hess-18-5361-2014, 2014.

Garssen, A. G., Verhoeven, J. T. A., and Soons, M. B.: Effects of climate-induced increases in summer drought on riparian plant species: a meta-analysis, Freshwater Biol., 59, 1052-1063, 2014.

Gobiet, A., Kotlarski, S., Beniston, M., Heinrich, G., Rajczak, J., and Stoffel, M.: 21st century climate change in the European Alps - A review, Sci. Total Environ., 493, 1138-1151, https://doi.org/10.1016/j.scitotenv.2013.07.050, 2014.

Goler, R. A. and Formayer, H.: Temporal disaggregation of daily meteorological data to 15-minute intervals for use in hydrological models, in: EMS Annual Meeting Abstracts, Vol. 9, EMS2012-174-1, available at: http://meetingorganizer. copernicus.org/EMS2012/EMS2012-174-1.pdf (last access: 11 January 2018), 2012.

Groom, J. D., Dent, L., Madsen, L. J., and Fleuret, J.: Response of western Oregon (USA) stream temperatures to contemporary forest management, Forest Ecol. Manag., 262, 1618-1629, https://doi.org/10.1016/j.foreco.2011.07.012, 2011.

Guldenschuh, M.: Longitudial zonation of habitat parameters and fish species assemblages in the Austrian lowland rivers Lafnitz and Pinka, M.S. thesis, University of Natural Resources and Life Sciences, Vienna, 2015. 
Haiden, T., Kann, A., Wittmann, C., Pistotnik, G., Bica, B., and Gruber, C.: The Integrated Nowcasting through Comprehensive Analysis (INCA) System and Its Validation over the Eastern Alpine Region, Weather Forecast., 26, 166-183, https://doi.org/10.1175/2010WAF2222451.1, 2011.

Hannah, D. M., Malcolm, I. A., Soulsby, C., and Youngson, A. F.: A comparison of forest and moorland stream microclimate, heat exchanges and thermal dynamics, Hydrol. Process., 22, 919-940, 2008.

Haylock, M. R., Hofstra, N., Klein Tank, A. M. G., Klok, E. J., Jones, P. D., and New, M.: A European daily highresolution gridded data set of surface temperature and precipitation for 1950-2006, J. Geophys. Res., 113, D20119, https://doi.org/10.1029/2008JD010201, 2008.

Heino, J., Virkkala, R., and Toivonen, H.: Climate change and freshwater biodiversity: detected patterns, future trends and adaptations in northern regions, Biol. Rev., 84, 39-54, https://doi.org/10.1111/j.1469-185X.2008.00060.x, 2009.

Holzapfel, G., Weihs, P., and Rauch, H. P.: Use of the Shade-a-lator 6.2 model to assess the shading potential of riparian purple willow (Salix purpurea) coppices on small to medium sized rivers, Ecol. Eng., 61P, 697-705, https://doi.org/10.1016/j.ecoleng.2013.07.036, 2013.

IPCC: The Physical Science Basis, Contribution of Working Group I to the Fifth Assessment Report of the Intergovernmental Panel on Climate Change, in: Climate Change 2013, edited by: Stocker, T. F., Qin, D., Plattner, G.-K., Tignor, M. M. B., Allen, S. K., Boschung, J., Nauels, A., Xia, Y., Bex, V., and Midgley, P. M., Cambridge University Press, Cambridge, United Kingdom and New York, NY, USA, 1535 pp., 2013.

Johnson, S.: Stream temperature: scaling of observation and issues for modelling, Hydrol. Process., 17, 497-499, 2003.

Johnson, S. L.: Factors influencing stream temperatures in small streams substrate effects and a shading experiment, Can. J. Fish. Aquat. Sci., 62, 913-923, 2004.

Johnson, M. F. and Wilby, R. L.: Seeing the landscape for the trees: metrics to guide riparian shade management in river catchments, Water Resour. Res., 51, 3754-3769, https://doi.org/10.1002/2014WR016802, 2015.

Citation of dataset: Kalny, G., Dossi, F., Formayer, H., Graf, W., Rauch, H.P, Trimmel, H., Weihs,P., Melcher, A.: Abiotic and biotic data of the rivers Pinka and Lafnitz 2012-2014, https://doi.org/10.13148/BFFWM8, 2016.

Kalny, G., Laaha, G., Melcher. , A., Trimmel, H., Weihs, P., and Rauch, H. P.: The influence of riparian vegetation shading on water temperature during low flow conditions in a medium sized river, Knowl. Manag. Aquat. Ecosyst, 418, 14 pp., https://doi.org/10.1051/kmae/2016037, 2017.

Kiermeyer, P.: Die Lebensbereiche der Gehölze, Verlagsges, Grün ist Leben, 108 pp., 1995.

Kothandaraman, V.: Analysis of Water Temperature Variations in Large Rivers, ASCE Journal of Sanitary Engineering Division, 97, 19-31, 1971.

Koutsoyiannis, D.: Rainfall disaggregation methods: Theory and applications, in: Proceedings of the Workshop on Statistical and Mathematical Methods for Hydrological Analysis, Universita degli Studi di Roma La Sapienza, Rome, 1-23, 2003.

Kurylyk, B. L., MacQuarrie, K. T. B., Caissie, D., and McKenzie, J. M.: Shallow groundwater thermal sensitivity to climate change and land cover disturbances: derivation of analytical expressions and implications for stream temperature modeling, Hydrol. Earth Syst. Sci., 19, 2469-2489, https://doi.org/10.5194/hess-19-24692015, 2015.

Kysel, J., Kalvová, J., and Květoň, V: Heat waves in the south Moravian region during the period 1961-1995, Stud. Geophys. Geod., 44, 57-72, 2000.

Leach, J. A. and Moore, R. D: Above-stream microclimate and stream surface energy exchanges in a wildfiredisturbed riparian zone, Hydrol Process., 24, 2369-2381, https://doi.org/10.1002/hyp.7639, 2010.

Ledochowski, V.: Changes of riparian vegetation and river morphology, as well as its influence on the water temperature at the river Pinka, Master thesis at the University of Natural Resources and Life Sciences, Vienna, 2014.

Lexer, M. J., Rabitsch, W.,, Grabherr, Dokulil, M., Dullinger, S., Eitzinger, J., Englisch, M., Essl, F., Gollmann, G., Gottfried, M., Graf, W., Hoch, G., Jandl, R., Kahrer, A., Kainz, M., Kirisits, T., Netherer, S., Pauli, H., Rott, E., Schleper, C., Schmidt-Kloiber, A., Schmutz, S., Schopf, A., Seidl, R., Vogl, W., Winkler, H., and Zechmeister, H.: Der Einfluss des Klimawandels auf die Biosphäre und Ökosystemleistungen/Climate Change Impact on the Biosphere and Ecosystem Services, in: Österreichischer Sachstandsbericht Klimawandel/Austrian Assessment Report 2014 (AAR14), Austrian Panel on Climate Change (APCC), Verlag der Österreichischen Akademie der Wissenschaften, Wien, Österreich, 468-556, 2014.

Li, G., Jackson, C. R., and Kraseski, K. A.: Modeled riparian stream shading: Agreement with field measurements and sensitivity to riparian conditions, J. Hydrol., 428/429, 142-151, https://doi.org/10.1016/j.jhydrol.2012.01.032, 2012.

Logez, M., Bady, P., Melcher, A., and Pont, D. A.: continentalscale analysis of fish assemblage functional structure in European rivers, Ecography, 36, 80-91, 2013.

Mader, H., Steidl, T., and Wimmer, R.: Ablussregime österreichischer Fliessgewässer, Umweltbundesamt/Federal Environment Agency - Austria, Wien, 1996.

Magnuson, J. J., Crowder, L. B., and Medvick, P. A.: Temperature as an Ecological Resource, Am. Zool., 19, 331-343, 1979.

Maheu, A., Caissie, D., St-Hilaire, A., and El-Jabi, N.: River evaporation and corresponding heat fluxes in forested catchments, Hydrol. Process., 28, 5725-5738, https://doi.org/10.1002/hyp.10071, 2014.

Matulla, C., Schmutz A., Melcher, A., Gerersdorfer, T., and Haas, P.: Assessing the impact of a downscaled climate change simulation on the fish fauna in an Inner-Alpine River, Int. J. Biometeorol., 52, 127-137, 2007.

Matulla, C., Schöner, W., Alexandersson, H., Storch, H., and Wang, X. L.: European storminess: late nineteenth century to present, Clim. Dynam., 31, 125-130, https://doi.org/10.1007/s00382007-033-y, 2008.

Melcher, A., Pletterbauer, F., Kremser, H., and Schmutz, S.: Temperaturansprüche und Auswirkungen des Klimawandels auf die Fischfauna in Flüssen und unterhalb von Seen, Österreichische Wasser- und Abfallwirtschaft, 65, 408-417, https://doi.org/10.1007/s00506-013-0118-y, 2013.

Melcher, A., Dossi, F., Wolfram Graf, Guldenschuh, M., Holzapfel, G., Lautsch, E., Leitner, P., Schaufler, K., Seebacher, M., Trimmel, H., Weihs, P., and Rauch, H. P.: Assessment of aquatic habi- 
tat availability and climate change effects in medium sized rivers, 10th ISE Trondheim, Norway, 2014.

Melcher, A., Pletterbauer, F., Guldenschuh, M., Rauch, P., Schaufler K., Seebacher, M., and Schmutz S.: Einfluss der Wassertemperatur auf die Habitatpräferenz von Fischen in mittelgroßen Flüssen, Mitteilungsblatt für die Mitglieder des Vereins für Ingenieurbiologie, Ingenieurbiologie: Neue Entwicklungen an Fließgewässern, Hängen und Böschungen, 1, 15-21, 2015.

Melcher, A., Kalny, G., Dossi, F., Formayer, H., Graf, W., Pletterbauer, F., Schaufler, K., Trimmel, H., Weihs, P., and Rauch, H. P.: Der Einfluss der Ufervegetation auf die Wassertemperatur unter gewässertypspezifischer Berücksichtigung von Fischen und benthischen Evertebraten am Beispiel von Lafnitz und Pinka, Österreichische Wasser- und Abfallwirtschaft, https://doi.org/10.1007/s00506-016-0321-8, 2016.

Mohseni, O., Stefan, H. G., and Erickson, T. R.: A nonlinear regression model for weekly stream temperatures, Water Resour. Res., 34, 2685-2692, 1998.

Moore, R. D., Spittlehouse D. L., and Story, A.: Riparian microclimate and stream temperature response to forest harvesting: a review, J. Am. Water Res. Assoc., 41, 813-834, 2005.

Muhar, S., Poppe, M., Egger, G., Schmutz, S., and Melcher, A.: Flusslandschaften Österreichs: Ausweisung von Flusslandschaftstypen anhand des Naturraums, der Fischfauna und der Auenvegetation. Bundesministerium für Bildung, Wissenschaft und Kultur, Wien, 2004.

Mühlmann, H.: Leitfaden zur hydromorphologischen Zustandserhebung von Fließgewässern, Bundesministerium für Land- und Forstwirtschaft, Umwelt und Wasserwirtschaft, Wien, 2010.

Nachtnebel, H. P., Dokulil, M., Kuhn, M., Loiskandl, W., Sailer, R., and Schöner, W.: Der Einfluss des Klimawandels auf die Hydrosphäre/Climate Change Impact on the Hydrosphere, in: Österreichischer Sachstandsbericht Klimawandel/Austrian Assessment Report 2014 (AAR14), Austrian Panel on Climate Change (APCC), Verlag der Österreichischen Akademie der Wissenschaften, Wien, Österreich, 411-466, 2014.

Pahr, A.: Geologische Karte der Republik Österreich, Blatt 137 Oberwart, Geologische Bundesanstalt, Wien, 1984.

Parker, F. L. and Krenkel, P. A.: Thermal pollution: status of the art, Department of Environmental and Resource Engineering, Vanderbilt University, Nashville, TN, 1969.

Pletterbauer, F., Melcher, A. H., Ferreira, T., and Schmutz, S.: Impact of climate change on the structure of fish assemblages in European rivers, Hydrobiologia, 744, 235-254, https://doi.org/10.1007/s10750-014-2079-y, 2015.

Primack, A. G. B.: Simulation of climate-change effects on riparian vegetation in the Pere Marquette River, Michigan, Wetlands, 20, 538-547, 2000.

Radu, R., Déqué, M., and Somot, S.: Spectral nudging in a spectral regional climate model, Tellus, 60, 898-910, 2008.

Rivaes, R. P., Rodríguez-González P. M., Terreira, M.T. Pinheiro, A N., Politti, E., Egger, G., García-Arias, A., and Francés, F.: Modeling the Evolution of Riparian Woodlands Facing Climate Change in Three European Rivers with Contrasting Flow Regimes, PLOS ONE, 9, e110200, https://doi.org/10.1371/journal.pone.0110200, 2014.

Roeckner, E., Bäuml, G., Bonaventura, L., Brokopf, R., Esch, M., Giorgetta, M, Hagemann, S., Kirchner, I., Kornblueh, L., Manzini, E., Rhodin, A., Schlese, U., Schulzweida, U., and Tompkins, A.: The atmospheric general circulation model ECHAM 5, PART I: Model description, Max Planck Institute for Meteorology, Report No. 349, 141 pp., 2003.

Roeckner, E., Brokopf, R., Esch, M., Giorgetta, M., Hagemann, S., Kornblueh, L., Manzini, E., Schlese, U., and Schulzweida, U.: The atmospheric general circulation model ECHAM5 - Part II: Sensitivity of simulated climate to horizontal and vertical resolution, Max Planck Institute for Meteorology, Report No. 354, 65 pp., 2004.

Roloff, A. and Bärtels, A.: Flora der Gehölze - Bestimmung, Eigenschaften, Verwendung, Ulmer, Stuttgart, 847 pp., 2006.

Rutherford, J. C., Blackett, S., Blackett, C., Saito, L., and DaviesColley, R. J.: Predicting the effects of shade on water temperature in small streams, New Zeal. J. Mar. Freshw., 31, 707-721, 1997.

Salas, J. D., Delleur, J. W., Yevjevich, V., and Lane, E. L.: Applied Modelling of Hydrological Time Series, Water Resources Publications, Colorado, p. 484, 1980.

San-Miguel-Ayanz, J., de Rigo, D., Caudullo, G., Houston Durrant, T., and Mauri, A. (Eds.): European Atlas of Forest Tree Species, Publication Office of European Union, Luxembourg, available at: http://forest.jrc.ec.europa.eu/ european-atlas-of-forest-tree-species/ (last access: 11 January 2018), 2016.

Schaufler, K.: Water temperature effects on fish in pre-alpine, medium-sized rivers, M.S. thesis, University of Natural Resources and Life Sciences, Vienna, 2015.

Schinegger, R., Trautwein, C., Melcher, A., and Schmutz, S.: Multiple human pressures and their spatial patterns in $\mathrm{Eu}-$ ropean running waters, Water Environ. J., 26, 261-273, https://doi.org/10.1111/j.1747-6593.2011.00285.x, 2012.

Settele, J., Scholes, R., Betts, R., Bunn, S. E., Leadley, P., Nepstad, D., Overpeck, J. T., and Taboada, M. A.: Global and Sectoral Aspects. Contribution of Working Group II to the Fifth Assessment Report of the Intergovernmental Panel of Climate Change, in: Terrestrial and inland water systems. Climate Change 2014: Impacts, Adaptation, and Vulnerability, edited by: Field, C. B., Barros, V. R., Dokken, D. J., Mach, K. J., Mastrandrea, M. D., Bilir, T. E., Chatterjee, M., Ebi, Estrada Y. O., Genova, R. C., Girma, B., Kissel, E. S., Levy, A. N., K. L., MacCracken, S., Mastrandrea, P. R., and White, L. L., Cambridge University Press, Cambridge, United Kingdom and New York, NY, USA, 271-359, 2014.

Sinokrot, B. A. and Stefan, H. G: Stream Temperature Dynamics: Measurements and Modeling, Water Resour. Res., 29, 22992312, 1993.

Skøien, J. O., Merz, R., and Blöschl, G.: Top-kriging - geostatistics on stream networks, Hydrol. Earth Syst. Sci., 10, 277-287, https://doi.org/10.5194/hess-10-277-2006, 2006.

Sridhar, V., Sansone, A. L., LaMarche, J., Dubin, T., and Lettenmaier, D. P.: Prediction of stream temperatures in forested watersheds, J. Am. Water Res. Assoc., 40, 197-213, 2004.

Steel, E. A. and Fullerton, A.: Thermal Networks - Do You Really Mean It?, StreamNotes - The Technical Newsletter of the National Stream and Aquatic Ecology Center, United States Departement of Agriculture, Fort Collins, Colorado, November, 2017.

Trimmel, H., Gangneux, C., Kalny, G., and Weihs, P.: Application of the model "Heat Source" to assess the influence of meteorological components on stream temperature and simulation ac- 
curacy under heat wave conditions, Meteorol. Z., 25, 389-406, https://doi.org/10.1127/metz/2016/0695, 2016.

Trimmel H., Kalny G., Dossi F., Formayer H., Graf W., Leitner P., Leidinger D., Nadeem I., Rauch H. P., Weihs P., and Melcher A.: Abiotic and biotic data of the rivers Pinka and Lafnitz 2012-2014, Freshwater Metadata Journal, 22, 1-12, https://doi.org/10.15504/fmj.2017.22, 2017.

van Vliet, M. T. H., Ludwig, F., Zwolsman, J. J. G., Weedon, G. P., and Kaba, P.: Global river temperatures and sensitivity to atmospheric warming and changes in river flow, Water Resour. Res., 47, W02544, https://doi.org/10.1029/2010WR009198, 2011.

van Vliet, M. T. H., Wiberg, D., Leduc, S., and Riahi, K.: Powergeneration system vulnerability and adaptation to changes in climate and water resources, Nature Climate Change, 6, 375-380, https://doi.org/10.1038/nclimate2903, 2016.

Webb, B. W. and Nobilis, F.: Long term water temperature trends in Austrian rivers, Hydrol. Sci. J., 40, 83-96, https://doi.org/10.1080/02626669509491392, 1995.
Webb, B. W. and Nobilis, F.: Long-term perspective on the nature of the air-water temperature relationship: a case study, Hydrol. Process., 11, 137-147, 1997.

Webb, B. W., Hannah, D. M., Moore, D. R., Brown, L. E., and Nobilis, F.: Advances in Stream and River Temperature Research, Hydrol. Process., 22, 902-918, 2008

Wenger, S. J., Som, N. A., Dauwalter, D. C., Isaak D. J., Neville, H M., Luce, C. H., Dunham, J. B., Young M. K., Fausch, K. D., and Rieman, B. E.: Probabilistic accounting of uncertainty in forecasts of species distributions under climate change, Glob. Change Biol., 19, 3343-3354, https://doi.org/10.1111/gcb.12294, 2013.

WRG: Wasserrechtsgesetz (water right law), BGBI. Nr. 215/1959, https://www.ris.bka.gv.at/GeltendeFassung.wxe?Abfrage= Bundesnormen\&Gesetzesnummer $=10010290$ (last access: 11 January 2018), 1959. 